\title{
First description of French V. tubiashii strains pathogenic to mollusk: I. Characterization of isolates and detection during mortality events
}

\author{
Marie-Agnès Travers ${ }^{a, *}, 1$, Rachida Mersni Achour ${ }^{a, b, c, 1}$, Philippe Haffner ${ }^{a}$, Delphine Tourbiez ${ }^{a}$, \\ Anne-Laure Cassone ${ }^{a}$, Benjamin Morga ${ }^{a}$, Ibtissem Doghri ${ }^{b}$, Céline Garcia ${ }^{a}$, Tristan Renault ${ }^{a}$, \\ Ingrid Fruitier-Arnaudin ${ }^{\mathrm{b}, \mathrm{c}, 2}$, Denis Saulnier ${ }^{\mathrm{a}, 3,2}$
}

\begin{abstract}
${ }^{a}$ Ifremer, SG2M-LGPMM, Laboratoire de Génétique et Pathologie des Mollusques Marins, Avenue de Mus de Loup, 17390 La Tremblade, France

b UMR 7266 CNRS-ULR, LIENSs, Equipe Approches Moléculaires, Environnement-Santé, Université de La Rochelle, Avenue Michel Crépeau, 17042 La Rochelle, France

${ }^{c}$ Fédération de Recherche en Environnement et Développement Durable, FR CNRS 3097, Université de La Rochelle, France
\end{abstract}

\footnotetext{
${ }^{1}$ Marie-Agnès Travers and Rachida Mersni Achour participated equally to this work and should be considered as primary co-authors.

${ }^{2}$ Ingrid Fruitier-Arnaudin and Denis Saulnier participated equally to this work and should be considered as last coauthors. ${ }^{3}$ Present address: Ifremer, Centre Ifremer du Pacifique, UMR EIO 241 Ecosystèmes Insulaires Océaniens, Tahiti,
98719 Taravao, French Polynesia.
} *: Corresponding author: Marie-Agnès Travers, Fax: +33 546762611 ;
email address : $\underline{\text { marie.agnes.travers@ifremer.fr }}$

\begin{abstract}
:
Nine dominant bacterial isolates were obtained from different batches of Crassostrea gigas spat experiencing high mortality rates in a French experimental hatchery/nursery in 2007. Using phenotypic analysis combined with multilocus sequence analysis, the isolates were shown to be genetically close to the Vibrio tubiashii type strain. Based on (1) analyses of the recA gene sequences; (2) the results of DNA-DNA hybridization assays between 07/118 T2 (LMG $27884=$ CECT 8426), which is a representative strain, and the $V$. tubiashii type strain (69\%); and (3) phenotypic traits, the bacteria were classified in a group close to American V. tubiashii strain. Its virulence ( $70 \%$ of mortalities) and the toxicity of the extracellular products of $07 / 118 \mathrm{~T} 2$ was demonstrated ( $41 \%$ of mortalities).
\end{abstract}

Moreover, a QPCR diagnostic tool targeting the $g y r B$ gene was developed to investigate the epidemiological significance of $V$. tubiashii in French oyster mortality outbreaks recorded by the national surveillance network. Of the 21 batches originating from hatcheries, only two were positive, whereas $V$. tubiashii DNA could not be detected in any of the batches of moribund animals collected in field/outdoor facilities. 
These results demonstrate the existence of a group of virulent $V$. tubiashii in France that episodically infect C. gigas.

\section{Graphical abstract}

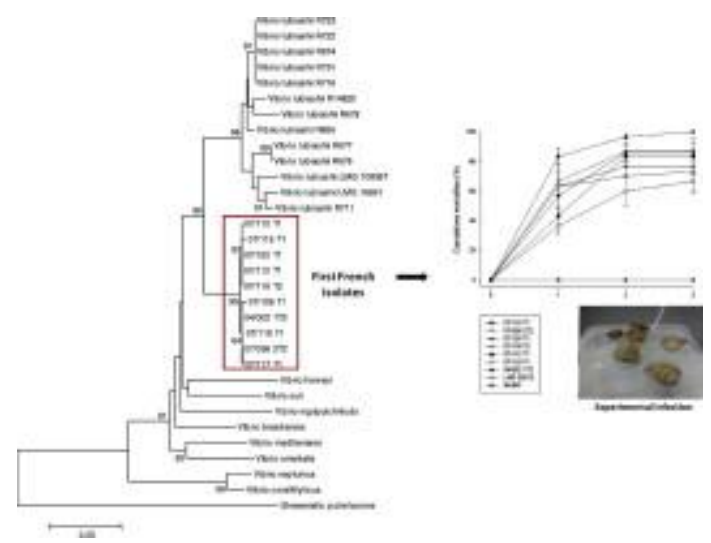

\section{Highlights}

First detection of $V$. tubiashii during mollusk mortality in France. French isolates are phylogenetically close but separated from American ones. French isolates are virulent to Pacific oyster and produce toxic ECPs. V V. tubiashii was episodically detected in France since 2004.

Keywords : Crassostrea gigas ; Pathogenicity ; Extracellular products ; Polyphasic approach, Real time PCR 


\section{Introduction}

The causes of abnormal mortalities during summer in Crassostrea gigas ( $C$. gigas) remains unclear although several studies suggest that this phenomenon has a complex etiology involving environmental stressors (oxygen depletion, lack of food, salinity, temperature, industrial pollution, pesticides, aquaculture practices) and biological factors that include pathogens and an altered physiology of the host (Samain et al., 2007). These mortalities can affect both diploid and triploid oysters, their different life stages (Romalde and Barja, 2010; De Decker et al., 2011) both in the field (for juveniles and adults) and in hatcheries (for larval and post-larval stages). Among the biological factors, microorganisms are often associated with oyster diseases. Three infectious microorganisms are frequently described as major pathogens of oysters : herpes-like viruses (Renault et al., 1994; Aguirre-Guzman et al., 2005), parasites (Meyers et al., 1991; Bower et al., 1997; Tun et al., 2008) and bacteria of the genus Vibrio which have been described as important causal agents affecting all life stages of bivalve mollusks (Le Roux et al., 2002; Garnier et al., 2008; Beaz-Hidalgo et al., 2010; Saulnier et al., 2010). V. splendidus and V. aestuarianus are presented as the two main Vibrio species associated with summer mortalities of $C$. gigas in France (Lacoste et al., 2001; Le Roux et al., 2002; Garnier et al., 2008). Besides these two major bacterial, another Vibrio species was reported by Saulnier et al. (2010) in a large-scale epidemiological study including nine virulent strains that belong to the $V$. harveyi group. The virulence of these strains was investigated by experimental infection on $C$. gigas spat. The results showed a strong correlation between the virulence of Vibrio and their capacity to produce metalloprotease-like activity in the culture supernatant, particularly for the strains 07/108 T1 and 07/118 T2. These two strains can secrete a high level of proteases and can induce extremely high levels of mortality just 20 hours post injection. Partial sequence analysis based on 16S rDNA revealed that 07/108 T1 and 07/118 T2 were clustered within the $V$. harveyi group.

Nevertheless, phenotypic analysis and the use of standard molecular techniques are insufficient to classify Vibrio, and indeed cannot even be used to identify related species. The identification of vibrios at the family and genus level are habitually based on 16S rDNA gene sequencing, but this method is unable to separate certain closely related species (Gomez-Gil et al., 2004). The association of other analyses, including DNA-DNA hybridization and molecular fingerprinting methods, is useful for Vibrio identification. However, these tools are restricted to some reference laboratories and inter-laboratory comparisons of fingerprint patterns are difficult (Thompson et al., 2005).

Multilocus sequence analysis (MLSA) has been adopted to fine-tune the approach and clarify certain doubts concerning Vibrio classification. Using this methodology, Thompson et al. have shown that $V$. harveyi. and $V$. campbellii form two separate clusters (Thompson et al., 2007) and $V$. communis and $V$. owensii, which were assigned to the Harveyi clade, were recently discovered to be the same species after identification using the MLSA approach (Hoffmann et al., 2012).

The aim of the present study was to refine the taxonomic affiliation of these virulent strains, previously clustered with $V$. harveyi, using a polyphasic approach (phenotypic and genotypic characterization). Secondly, quantitative challenges with live bacteria and in vitro culture supernatants were performed with $C$. gigas in order to evaluate their virulence and the toxicity of the extracellular products, respectively. Finally, a quantitative real-time PCR diagnostic tool was developed to screen isolates/DNA collected during the episodes of mortality that have occurred in France since 2004 and evaluate their epidemiological significance. 


\section{Materials and methods}

\subsection{Taxonomic affiliation}

\subsubsection{Bacteria genotyping and phylogenetic analyses (10 isolates)}

The strains used in this study are described in Table 1. The predominant bacteria, which have not been yet described, were isolated, as previously done by Saulnier et al. (2010), during the mortalities recorded in oyster hatchery stocks in 2007. Briefly, after $10^{-2}$ and $10^{-3}$ dilutions in Sterile Artificial Sea Water (SASW : $2.3 \%$ (w/v) NaCl, $20 \mathrm{mM} \mathrm{KCl,} 5 \mathrm{mM} \mathrm{MgSO}_{4}$, $2 \mathrm{mM} \mathrm{CaCl}$ ), moribund oyster samples (hemolymph for adults and crushed tissues for juveniles) were plated on thiosulfate-citrate-bile salts-sucrose (TCBS, Difco ${ }^{\mathrm{TM}}$ ), Zobell agar (0.4\% peptone, $0.1 \%$ yeast extract, $0.01 \%$ ferric citrate and $1.5 \%$ agar in SASW, pH 7.6 ) or marine agar (Conda) and the predominant bacteria were isolated after $48 \mathrm{~h}$ at $20^{\circ} \mathrm{C}$. Pure cultures of bacterial strains were conserved frozen at $-80^{\circ} \mathrm{C}$ in Zobell broth with glycerol $15 \%$.

For genotyping, DNA was extracted following the FTA $^{\circledR}$ procedure (Whatman). Bacterial isolates were cultured during 24 hours at $20{ }^{\circ} \mathrm{C}$ in Zobell broth and $65 \mu \mathrm{l}$ of bacterial suspension at the stationary phase of in vitro culture was deposited on FTA ${ }^{\circledR}$ paper matrix cards according to the manufacturer's instructions. Briefly, a punch from the FTA ${ }^{\circledR}$ Card was washed three times with FTA ${ }^{\circledR}$ Purification Reagent and rinsed with $200 \mu$ of TE buffer (10 $\mathrm{mM}$ Tris- $\mathrm{HCl}, 0.1 \mathrm{mM}$ EDTA, $\mathrm{pH}$ 8). This punch was either directly transferred into a PCR tube, or conserved at $-20^{\circ} \mathrm{C}$ before use.

The 16S rRNA (ribosomal RNA), ftsZ (cell division protein, cell division), pyrH (uridylate kinase, nucleotide biosynthesis), recA (recA protein, DNA repair) and topA (topoisomerase I, DNA replication and repair) genes were amplified using the universal bacterial primer pairs listed in supplementary Table 1 and the methods previously described (Thompson et al., 2005). Amplicons with the expected size were purified using a Microcon PCR filter kit (Millipore). Purified PCR products were mixed (final volume $10 \mu \mathrm{l}$ ) with $0.4 \mu \mathrm{l} \mathrm{ABI}$ Prism Big Dye Terminator ready reaction mix (Applied Biosystems ${ }^{\circledR}$ ) and $0.75 \mu \mathrm{M}$ of primer. Cycle sequencing reactions were performed using a Gene Amp PCR System 2700 (Applied Biosystems ${ }^{\circledR}$ ) and following the manufacturer's instructions. Separation of the DNA fragments was carried out in an ABI PRISM 3100 Genetic Analyzer (Applied Biosystems).

Sequences were aligned using ClustalW http://www.ebi.ac.uk/Tools/msa/clustalw2/ and BioEdit software http://www.mbio.ncsu.edu/bioedit/bioedit.html. Pairwise similarity was calculated with BioEdit.

Phylogenetic trees were built using Mega4 http://www.megasoftware.net/mega4/mega.html. The trees were drawn using the Neighbor-Joining method with the Kimura two-parameter model (Saitou and Nei, 1987) and the maximum parsimony method (Eck and Dayhoff, 1966). Reliability of topologies was assessed by the bootstrap method (Felsenstein, 1985) with 1000 replicates. The Genbank accession numbers for the $16 \mathrm{~S}$ rDNA, gyrB, recA, topA, pyrH, fts $Z$ gene sequences obtained in this study or already published in GenBank are presented in Supplementary Table 3.

\subsubsection{DNA-DNA hybridization assays (2 isolates)}

DNA-DNA hybridization (DDH) was performed by the $\mathrm{BCCM}^{\mathrm{TM}} / \mathrm{LMG}$ laboratory at Gent University. After a genomic DNA extraction according to a modified Wilson protocol (Wilson, 
1987), hybridizations were performed in microplates at $40^{\circ} \mathrm{C}$ (Ezaki et al., 1989) and DNA relatedness values (\%) reported were the means of a minimum of 6 hybridizations.

\subsubsection{Bacteria phenotypic characterization (10 isolates)}

The phenotypes of the selected isolates were characterized in different ways. Bacteria growth on TCBS medium (AES Chemunex), chromID TM Vibrio medium (Biomérieux) and CHROMagar ${ }^{\mathrm{TM}}$ Vibrio medium (CHROMagar) was observed. The capacity of bacteria to grow in Zobell broth with 8 and $10 \% \mathrm{NaCl}$ at $22^{\circ} \mathrm{C}$ was determined and the ability of bacteria to grow on Zobell agar at $40^{\circ} \mathrm{C}$ was established.

Antibiograms were carried out using disc diffusion assays on Mueller-Hinton agar (Oxoid) with commercial impregnated discs (Oxoid): Flumequine $30 \mu \mathrm{g}$ (UB30), Kanamycin $30 \mu \mathrm{g}$ (K30), Tetracycline $30 \mu \mathrm{g}$ (TE30), Sulphamethoxazole/trimethoprim 19:1 $25 \mu \mathrm{g}$ (SXT25), Streptomycin $25 \mu \mathrm{g}$ (S25), Sulphonamides $300 \mu \mathrm{g}$ (S3), Erythromycin $30 \mu \mathrm{g}$ (E30), Penicillin $10 \mathrm{UI}(6 \mu \mathrm{g})(\mathrm{P} 10)$, Trimethoprim $5 \mu \mathrm{g}$ (W5), Chloramphenicol $30 \mu \mathrm{g}$ (C30), Ampicillin $10 \mu \mathrm{g}$ (AMP10), Gentamicin $30 \mu \mathrm{g}$ (CN30) or the Vibriostatic agent, Pteridine $150 \mu \mathrm{g}$ and $10 \mu \mathrm{g}$ $(\mathrm{O} 129 / 150$ and $\mathrm{O} 129 / 10)$. Inhibition was observed after 24 to $48 \mathrm{~h}$ at $22^{\circ} \mathrm{C}$ on Zobell agar. API 20E, API 20NE and API 50CH (Biomérieux) were used in accordance with the manufacturer's recommendations. Fresh colonies, obtained from culture bacteria on TSA $\left(\right.$ Difco $^{\mathrm{TM}}$ ) adjusted to $2 \% \mathrm{NaCl}$, were suspended in SASW to obtain about $\mathrm{OD}_{600}=0.1$. After inoculation, the strips were incubated for $48 \mathrm{~h}$ at $22{ }^{\circ} \mathrm{C}$ and the results were determined according to the manufacturer's instructions.

\subsection{Pathogenicity assays}

\subsubsection{Bacterial virulence tests (7 isolates)}

Bacteria (07/038 2T2, 07/110 T1, 07/112 T1, 07/120 T1, 07/119 T1, 07/118 T2 and 04/002 1T2) were grown at $22{ }^{\circ} \mathrm{C}$ for $20 \mathrm{~h}$ in marine broth with constant shaking at $40 \mathrm{rpm}$ (Rotator SB3; Stuart). The bacterial concentrations in the cultures were evaluated spectrophotometrically at an optical density (OD) of $600 \mathrm{~nm}$ and checked by plating. The cells were centrifuged at $3,200 \times \mathrm{g}$ for $10 \mathrm{~min}$, the supernatant discarded and the resulting pellet resuspended in SASW to obtain an OD $600 \mathrm{~nm}$ of 1. Ten to twelve-month-old oyster spat were anesthetized for 1 to 2 hours at $22{ }^{\circ} \mathrm{C}$ in a magnesium chloride solution $\left(\mathrm{MgCl}_{2}\right.$, Fluka) at a final concentration of $50 \mathrm{~g} \mathrm{I}^{-1}(1 / 4: \mathrm{v} / \mathrm{v}$ seawater/freshwater) and under aeration. Subsequently, $100 \mu \mathrm{l}$ of bacterial suspension (10 $\mathrm{cfu}$ per oyster) was injected into the adductor muscle. A group of oysters were injected with SASW to serve as negative controls. After injection, the oysters were transferred to tanks (triplicates of 10 oysters in 2 liters) filled with UV-treated and $1 \mu \mathrm{m}$-filtered seawater at $3.1 \%$ salinity and maintained under static conditions at $22{ }^{\circ} \mathrm{C}$ with aeration. Mortality was monitored twice a day and any newly dead oysters were removed from the tanks over a four day period. Animals were considered to be dead when the valves did not close following stimulation.

\subsubsection{Toxicity and characterization of ECPs from the $\mathrm{V}$. tubiashii $07 / 118 \mathrm{~T} 2$}

Bacterial extracellular products (ECPs) from 07/118 T2 were produced in two types of culture medium, plate agar and liquid medium. For culture in liquid medium: bacteria were grown on Luria-Bertani (Difco ${ }^{\mathrm{TM}}$ ) medium supplemented with $1 \%$ sodium chloride (LBS-1\% $\mathrm{NaCl}$ ). Briefly $100 \mu \mathrm{l}$ of a pre-culture of bacteria (OD ${ }_{600}$ of 1 ) was cultured in $100 \mathrm{ml}$ of LBS medium 
in a $500 \mathrm{ml}$ Erlenmeyer flask at $22^{\circ} \mathrm{C}$ with constant shaking at $100 \mathrm{rpm}$ (Aquatron, INFORS $\mathrm{HT}$ ). After $24 \mathrm{~h}$ of incubation, ECPs were obtained by centrifugation at 3,000 $\times \mathrm{g}$ for $40 \mathrm{~min}$ at $4^{\circ} \mathrm{C}$. The supernatant containing the ECPs was filtered at $0.22 \mu \mathrm{m}$ and then concentrated by lyophilisation. The concentrated sample was resuspended in Tris- $\mathrm{HCl}$ buffer $(50 \mathrm{mM}$ Tris$\mathrm{HCl}, \mathrm{pH}$ 8.0) and dialyzed against distillated water in the first step for $12 \mathrm{~h}$ and against Tris$\mathrm{HCl}$ buffer for $12 \mathrm{~h}$ in the second step. Finally, the samples were stored at $-80^{\circ} \mathrm{C}$ until use. For culture on solid medium: ECPs were produced using the cellophane plate technique described by Liu (1957). A volume of $1 \mathrm{ml}$ of exponential phase culture in LBS $\left(\mathrm{OD}_{600}\right.$ of 1 , $22^{\circ} \mathrm{C}$ for $18 \mathrm{~h}$ ) was spread on a sterile cellophane film overlying LBS agar (LBSA) plates. After $48 \mathrm{~h}$ of culture at $22^{\circ} \mathrm{C}$, the cells were washed off the cellophane using $10 \mathrm{ml}$ of cold SASW and removed by centrifugation at $3,000 \times \mathrm{g}\left(45 \mathrm{~min}\right.$ at $\left.4^{\circ} \mathrm{C}\right)$. The supernatant containing the ECPs was then treated in the same way as the ECPs from liquid media.

The toxicity of both ECPs was tested as follows: a volume of $100 \mu \mathrm{l}$ of ECP solution, adjusted in Tris-HCl buffer to a concentration of $5 \mu \mathrm{g} \mathrm{g}^{-1}$ of soft body weight, was injected into the adductor muscle of ten to twelve month-old oyster spat after anesthetizing them (see above). A group of oysters used as controls were injected with SASW and Tris- $\mathrm{HCl}$ buffer. Mortality was monitored twice a day and any newly dead oysters were removed from the tanks. ECPS proteins concentration was determined using the method described by Bradford (using Bradford Reagent,_from Sigma -Aldrich) with bovine albumin serum as a standard (SigmaAldrich).

The proteolytic activity was determined using azocasein (Sigma-Aldrich) as a substrate according to the method of Teo et al (2003) with some modifications. Briefly, $100 \mu \mathrm{l}$ of a suitable dilution of ECP solution (1/10 v/v) was added to $100 \mu \mathrm{l}$ of azocasein $\left(5 \mathrm{mg} \mathrm{ml}^{-1}\right.$ in 50 $\mathrm{mM}$ Tris- $\mathrm{HCl}, \mathrm{pH} 8.0$ ). The mixture was incubated at $22^{\circ} \mathrm{C}$ for $2 \mathrm{~h}$ in darkness and stirred constantly. The reaction was stopped by adding $200 \mu \mathrm{l}$ of $10 \%$ trichloroacetic acid. The mixture was centrifuged at $12,000 \times \mathrm{g}$ for $10 \mathrm{~min}$ and $50 \mu \mathrm{l}$ of the supernatant was added to $50 \mu \mathrm{l}$ of $1 \mathrm{M} \mathrm{NaOH}$ in 96 well plates (Nunc/Thermo Scientific). The absorbance was measured at $440 \mathrm{~nm}$ in a microplate reader (Molecular Devices). One unit of azocaseinase activity was defined as the amount of crude ECPs that caused an increase of 0.01 absorbance unit after a $2 \mathrm{~h}$ incubation at $22^{\circ} \mathrm{C}$.

The stability of the proteolytic activity was determined by incubating ECPs from LBSA for 24 $\mathrm{h}$ and $48 \mathrm{~h}$ at $22^{\circ} \mathrm{C}$ without substrate. After the preincubation, the azocaseinase activity was measured according to the protocol described previously.

The effect of 1,10-phenantroline on proteolytic activity was examined. Stock solutions of 1,10-phenantroline (Sigma-Aldrich) were dissolved in a small volume of absolute ethanol (until total solubilization) and adjusted to the appropriate concentration with Tris- $\mathrm{HCl}$ buffer. Briefly, $25 \mu \mathrm{l}$ of inhibitor, diluted to the appropriate concentrations, was pre-incubated with 25 $\mu \mathrm{l}$ of ECPs for $30 \mathrm{~min}$ at $22^{\circ} \mathrm{C}$ and the proteolytic activity was then measured (see above). Residual azocaseinase activity was calculated on the basis of assays run in the absence of inhibitor.

\subsection{Quantitative real-time PCR diagnostic tool}

\subsubsection{Diagnostic tool development (2 isolates)}

Oligonucleotide sequences were derived from the sequence alignment of the gyrB (DNA gyrase B subunit, basic replication machinery) gene in different Vibrio species, including the $V$. tubiashii type strain and the sequence obtained from the 07/118 T2 and 07/112 T2 strains with the primers listed in supplementary Table 1. Primer 3 software http://frodo.wi.mit.edu/ 
was used to design a real-time PCR probe (Table S1) and forward and reverse PCR primers. The probes consists of an oligonucleotide dually labeled with a 5'- reporter dye and the downstream 3'-quencher dye indicated Table S1 (Eurogentec). The probe and primers were assessed for species specificity using a BLAST search to determine homology to known sequences.

A Real-time PCR assay was conducted on MX3000 and MX3005 Thermocyclers (Agilent) using Brilliant III Ultrafast kit (Stratagene). Each reaction was run in duplicate in a final volume of $20 \mu \mathrm{l}$ containing various concentrations of a DNA sample $(5 \mu \mathrm{l}), 200 \mathrm{nM}$ of each primer and $200 \mathrm{nM}$ of oligonucleotidic probe. The thermal cycle was performed with a twostep PCR protocol: 1 cycle at $95{ }^{\circ} \mathrm{C}$ for 3 min followed by 40 cycles at $95{ }^{\circ} \mathrm{C}$ for $10 \mathrm{~s}$ and $60^{\circ} \mathrm{C}$ for $20 \mathrm{~s}$. Fluorescence intensity was expressed in delta reporters (dR) after background subtraction. The threshold was set using an amplification based algorithm from the MX30003005 software (Stratagene) for the initial plate. Amplicons were sequenced to check primers specificity. Serial dilutions were performed on genomic DNA extracts quantified by spectrophotometry (Nanodrop/Thermo Scientific) and adjusted to $10^{8}$ bacteria/ml $=1.05 \mathrm{ng} / \mathrm{\mu l}$ (for the 5,353 kbp V. tubiashii genome).

\subsubsection{Screening on DNA isolated from mollusks}

Zoosanitary monitoring was performed by the REPAMO network (REseau de PAthologie des MOllusques) between 2003 and 2012. During this period 254 batches of animal samples were collected from abnormal mortality episodes affecting Crassostrea gigas oysters, Haliotis tuberculata abalone, Venerupis philippinarum clams and Pecten maximus scallops. Samples from 49 of these batches were analyzed in this work. They were selected to provide a range of origin (hatchery/field), year of sampling, age and ploidy of the animals. The isolation of dominant bacteria was carried out between 2003 and 2012 on animals that were moribund on their arrival in the laboratory. Total DNA from infected animals was systematically extracted between 2003 and 2012. Depending on mollusk species and the age of the animals, different tissues were sampled in sterile conditions for bacteriological analysis: haemolymph was taken for each oyster or abalone; a piece of adductor muscle, gill and mantle mixed together for each scallop; and a mixture of five mantles from individual clams. All these tissues were prepared using five individuals or five pools of animals from each batch, and in each case this corresponded either to an all-adult or all-juvenile age class. Haemolymph was drawn into a syringe from the adductor muscle or pericardial cavity of oysters and from the pericardial cavity of abalone using a 23-gauge needle. Tissues from scallop and clams were homogenized in $100 \mu \mathrm{l}$ of SASW with a sterile pellet-pestle (Sigma) for 1 minute on average. For larvae and early spat stages (shell size smaller than $3 \mathrm{~cm}$ in length), several whole animals were taken and disrupted in SASW as a single pool of individuals for each batch sample.

Bacterial DNA from a log-phase culture was extracted from cultured Vibrio either by boiling in $200 \mu \mathrm{l}$ of ultra pure water (Saulnier et al., 2009) or using the standard QIAmp DNA mini kit (Qiagen) procedure. After extracting DNA according to the manufacturer's instructions, the pelleted DNAs were resuspended in $100 \mu \mathrm{l}$ of $\mathrm{AE}$ buffer and stored at $-20^{\circ} \mathrm{C}$. DNA yield and purity were determined by spectrophotometry (Nanodrop/Thermo Scientific). DNA from the crushed tissues of mollusk was extracted using a similar QIAmp DNA mini kit (Qiagen) method. 


\section{Results}

\subsection{Genetic and biochemical characterization of bacterial strains isolated in 2004 and 2007}

Bacterial strains were isolated during the period in which the REPAMO surveillance network reported high levels of mollusk mortalities in hatcheries. In 2007, in an experimental hatchery/nursery in France, nine batches of oyster juveniles and adults (either diploids or triploids) experienced heavy mortalities. Nine predominant bacterial strains were isolated from these batches on TCBS plates (Table 1). After isolation, the bacteria appeared small (1$2 \mathrm{~mm}$ ), opaque, regular, white to cream-colored on marine agar and yellow on TCBS after 48 h at $20^{\circ} \mathrm{C}$.

Initial phylogenetic analyses based on the 16S rRNA gene sequence of these strains led to their classification in the $V$. harveyi group (Saulnier et al., 2010). One other strain from the French REPAMO bacterial collection (04/002 1T2 = LMG $27885=$ CECT 8427) had a similar 16S rRNA gene sequence (more than $99.8 \%$ mutual $16 \mathrm{~S}$ rRNA gene sequence similarity) and was added to the other analyses.

A multilocus sequence analysis based on the conserved genes $16 \mathrm{~S}$ rRNA, ftsZ, topA, pyrH and $\operatorname{rec} A$ confirmed the tight grouping of these isolates. They were most closely related to the $V$. tubiashii LMG10936 type strain but appeared in a distinct cluster as revealed by the high bootstrap value of 100 (Fig. 1). Phylogenetic analysis with the maximum parsimony or the neighbor joining algorithms produced congruent results revealing the reliability of the obtained phylogenetic tress (Not shown). Similarities between the $V$. tubiashii type strain LMG10936 and the novel isolates were $97-97.5 \%$ for 16 S rDNA, 98-99\% for $\mathrm{ftsZ}, 92-96 \%$ for topA, and $91-97 \%$ for $p y r H$ and for $\operatorname{rec} A$ (sequences alignment is presented in Supplementary Table 4).

The $\operatorname{rec} A$ gene showed the highest resolution for differentiating $V$. tubiashii related strains. Phylogenetic analysis of this gene provides strong evidence that the French isolates form a distinct group from the North American ones (Fig. 2), presenting nucleotidic sequence similarities around 94-95\% (sequences alignment is presented in Supplementary Table 5).

This classification was confirmed by DNA-DNA hybridization (DDH) of two of the strains that were isolated from diseased oysters in 2007 or diseased abalone in 2004 (Table 2). DDH between the novel isolates 07/118 T2 (= LMG 27884= CECT 8426) and 04/002 1T2 (= LMG $27885=$ CECT 8427) indicated $86 \%$ genomic similarity, confirming that they belong to the same species. The isolates 07/118 T2 and 04/002 1T2 had 69\% DNA-DNA relatedness with the $V$. tubiashii type strain LMG 10936T, which is just under the border value accepted for the delineation of prokaryotic species (Wayne et al., 1987).

Additional tests such as biochemical characterization, temperature and salinity tolerance and antibiotic sensitivity were performed to decide whether to allocate the strains to the $V$. tubiashii species or to a new species.

Of the 31 parameters measured, only two majoritary traits differed (but inconsistently according to the used strains) between the other $V$. tubiashii related strains and our strains (acid production from citrate and cellobiose), clearly demonstrating the relatedness with the V. tubiashii species (Table 3). All our isolates were positive for cellobiose utilization while this character appeared variable for V. tubiashii strains (Hada et al., 1984). Conversely, citrate utilization is a variable characteristic of our isolates ( 7 positive / 10 tested strains). 
Moreover, our strains were able to produce acid from melibiose, which is one of the specific characteristics of $V$. tubiashii.

In conclusion, with 69\% DNA-DNA relatedness with $V$. tubiashii type strains, two phenotypic variables differences revealed by majoritary trait analysis and distinct grouping by MLST analysis, our isolates should be considered as $V$. tubiashii and not as a new species.

\subsection{Pathogenicity assays}

The pathogenicity of seven French isolates (07/038 2T2, 07/110 T1, 07/112 T1, 07/120 T1, 07/119 T1, 07/118 T2 and 04/002 1T2) was investigated by experimental infections that also included a non virulent strain, LMG20012T (Fig. 3). One year-old oysters were intra muscularly injected with these bacterial suspensions used at the same concentration. After $24 \mathrm{~h}$, cumulative mortalities were comprised between $36.7 \%$ and $83.3 \%$ indicating that these seven isolates had different degrees of virulence. 07/110 T1, 07/038 2T2, 07/120 T1 and $07 / 118 \mathrm{~T} 2$ were the most virulent and caused more than $60 \%$ mortality after $24 \mathrm{~h}$. $07 / 112 \mathrm{~T} 1$, $07 / 119 \mathrm{~T} 1$ and 04/002 1T2 caused less than $60 \%$ mortality at $24 \mathrm{~h}$ but all the isolates induced more than $60 \%$ mortality after 3 days. In some moribund oysters, several predominant bacterial isolates were obtained in muscle and haemolymph tissues. All bacterial isolates were found to belong to $V$. tubiashii species using our gyrB-QPCR diagnosis assay.

In parallel, the toxicity of ECPs from 07/118 T2 produced on agar plates (LBSA) and in liquid medium (LBS) was tested by experimental infections. A mortality of $41 \%$ was observed two days after injecting oysters with ECPs produced on LBSA (Fig. 4A). However, no mortality was observed with ECPs produced in LBS. Similarly, no mortality of control oysters was observed during the experiments with Tris- $\mathrm{HCl}$ buffer or SASW.

\subsection{Characterization of proteolytic activity of $07 / 118$ T2 ECPs}

The proteolytic activity of ECPs from 07/118 T2 (in liquid and solid medium) was severely reduced by metalloprotease inhibitor (1,10-phenanthroline), with residual activities of $5 \%$ and $25 \%$ for ECPs produced on LBS and LBSA, respectively (Fig. 4). For the stability of ECPs produced on LBSA, $80 \%$ of the protease activities was maintained 48 hours postincubation at $22^{\circ} \mathrm{C}$ (Fig. $4 \mathrm{~B}$ ).

\subsection{Development of a QPCR assay and hatchery- and field-samples screening}

The gene encoding gyrase $\mathrm{B}(\mathrm{gyr} B)$ in the $07 / 112 \mathrm{~T} 2$ and $07 / 118 \mathrm{~T} 2$ strains was sequenced (KF270490 and KF270491 respectively). After sequence alignments with the $V$. tubiashii type strain and closely related strains ( $V$. hepatarius, $V$. orientalis, $V$. brasiliensis, $V$. coralliilyticus, $V$. neptunius, $V$ harveyi and $V$. xuii), species-specific $(g y r B)$ primers and probes were designed. The gyrB primers and probes were designed to amplify all $V$. tubiashii isolates.

The concentration of the primers and probes was optimized at $200 \mathrm{nM}$. Using these conditions, excellent real time PCR efficiencies were obtained by 10 -fold dilutions of $07 / 118$ T2 and $V$. tubiashii type strain DNAs, $99.2 \%$ and $96.3 \%$ respectively (Fig. S1). Finally, the specificity was investigated on different bacterial DNA extracts (Table 1). Among 20 tested strains including 7 type strains belonging to different Vibrio species, only all tested $V$. 
tubiashii strains ( $\mathrm{n}=13$, including the type strain) were found positive. By considering $\mathrm{Ct}$ above cycle 38, our QPCR assay appeared to be specific and able to detect more than $10^{3}$ bacteria/ml (Fig. S1).

Using this new diagnostic tool, the French LNR hatchery and field DNA collection were screened. These DNA were extracted from oysters tissues sampled in a context of declared mortalities analyzed by the REPAMO network. Of the 49 batches of animals ( 379 samples), only DNA from two batches were positive with the $V$. tubiashii diagnostic tool. These batches came from two different French hatcheries (2 positive batches from the 21 analysed) (Table S2). On the 28 batches of moribund animals from the field collection, all were negative for the presence of $V$. tubiashii DNA.

\section{Discussion}

The aims of the present study were (1) to fine-tune the taxonomic affiliation of virulent strains collected during an episode of high level Crassostrea gigas mortality in France using a polyphasic approach (phenotypic and genotypic characterization); (2) to evaluate both their virulence and the toxicity of their extracellular products; and (3) to investigate the geographical distribution of these bacteria.

The strains used in this study were isolated from an experimental hatchery/nursery in France in 2007, during a period of heavy oyster mortalities, under the auspices of the French institutional surveillance network, REPAMO.

Hatchery systems provide ideal conditions for the growth of larvae and bacteria multiplication (density, temperature, organic matter load, etc.) (Prado et al., 2005). Furthermore, farmed animals are monitored daily, allowing precise observations of mortality and investigations into pathogens. Hatcheries are therefore ideal places for the isolation of bacteria and the description of new bacterial species (Sugumar et al., 1998; Estes et al., 2004; Gay et al., 2004; Labreuche et al., 2006a; Elston et al., 2008).

For mollusks pathogens, the investigation of the pathogenic potential of a particular strain is still in its infancy due to the absence of animal models, cloned or knock-out animals for in vivo studies, or the availability of culture cell lines for in vitro assays. Furthermore, the virulence of Vibrio species is known to involve many virulence factors and different pathways (Shinoda and Miyoshi, 2011) and there is a lack of standardized in vitro protocols for virulence phenotype characterization.

In an in vivo assay, bacteria can be injected into animal muscle (injection (Gay et al., 2004)), put into seawater surrounding the animals after a culture phase (immersion or bath challenge (Travers et al., 2008; Segarra et al., 2010)), or transmitted by cohabitation challenges (De Decker and Saulnier, 2011). Even if they rely on the injection of large quantities of cultured bacteria, bypass the penetration step and consequently the first lines of defense, injection protocols are still the most reproducible and widely-used methodology for initial Vibrio challenges (Labreuche et al., 2006a; Gagnaire et al., 2007; Garnier et al., 2007; Williams et al., 2009). In this study, this protocol was applied to our isolated strains and allows the demonstration of the high degree of virulence of the strains into oyster tissues (between 36.7 and $83.3 \%$ of mortality as soon as 24 hours post-injection). This mortality rate is comparable to the one induced by other Vibrio species when used at same dose that the present study: $V$. aestuarianus $(02 / 041)$ induced $62.5 \%$ of mortality eight days post-infection (Labreuche et al., 2006a) and the co-infection of a mix of two Vibrio (V. splendidus LGP 32 and $V$. 
aestuarianus 02/041) gave a mean mortality rate of $88.9 \%$ five days post-infection (De Decker and Saulnier, 2011).

After isolating the bacteria and demonstrating their high level of virulence, a precise classification was needed. Initial identification of strains isolated in 2007, based on partial 16S rDNA analysis, led to the affiliation of these strains to the $V$. harveyi species (Saulnier et al., 2010). It is difficult to classify them as part of the Vibrio clades, and particularly the $V$. harveyi clade, based on $16 \mathrm{~S}$ rDNA analysis. A reliable classification needs to be supported by sequence analyses of multiple housekeeping genes (Thompson et al., 2005). Here, this analysis with $16 \mathrm{~S}$ rDNA, fts $Z$, topA, pyrH and recA showed a tight grouping of 07/118 T2 with other French isolates and close to the $V$. tubiashii type strain, but clearly distinct from $V$. tubiashii group. This was confirmed by the DNA-DNA hybridization of two selected strains (04/002 1T2 and 07/118 T2) and phenotypic characterization based on 31 different parameters (salt, temperature and antibiotic sensitivity, sugar utilization, enzymatic activities). Although DNA-DNA hybridization with the V. tubiashii type strain was below $70 \%$ (69\%), as biochemical assays do not allow a clear distinction between our isolates and the $V$. tubiashii strains, we propose to affiliate the 07/118 T2 (LMG $27884=$ CECT 8426T) strain and other proximate isolates to a group belonging to the $V$. tubiashii species.

V. tubiashii, misclassified until 1984, was first implicated in bivalve mortalities on the east coast of the United States (Tubiash et al., 1965; Tubiash et al., 1970; Hada et al., 1984). In the eighties, in England, three virulent isolates of $V$. tubiashii were described that were pathogenic for Crassostrea gigas and Ostrea edulis larvae (Jeffries, 1982). More recently, in 2006 and 2007, some V. tubiashii strains were detected on the north American Pacific coast that caused a serious loss of hatchery production (Estes et al., 2004; Elston et al., 2008). The associated disease was characterized by a rapid appearance of symptoms resulting in reduced larval motility and necrosis in extensive soft tissue (Kothary et al., 2001).

It is important to note that our isolates are close but clearly separated to those from the USA. Interestingly, a strain isolated during a mortality episode of Haliotis tuberculata abalone (Normandy, 2004; 04/002 1T2 = LMG 27885 = CECT 8427) clusters with other french $V$. tubiashii. V. tubiashii has therefore been present in France since at least 2004. This strain can also induce high mortality in $C$. gigas oysters after intramuscular injection. In contrast to work on other Vibrio demonstrating a specific virulence for their natural hosts (Saulnier et al., 2000; Travers et al., 2009), one V. tubiashii virulent strain seems to affect both oysters and abalone, even if virulence has not yet experimentally demonstrated on abalone.

Vibrio tubiashii is a pathogen that is known to affect hatchery and nursery production and cause serious financial losses. Specific and sensitive detection tools are therefore necessary. A previously described, real time PCR assay targeting the $V$. tubiashii vtpA gene (Gharaibeh et al., 2009) was tested but we encountered specificity issues (data not shown). Taqman real time PCR based on the dnaJ sequence has also been used to detect and quantify V. aestuarianus (Saulnier et al., 2009). This technique is sensitive, rapid and reproducible, irrespective of the nature of the sample (seawater or oyster homogenate samples). In this paper, a taqman real time PCR diagnostic tool was developed to investigate the distribution of $V$. tubiashii in France and its potential implication in mollusk mortalities. Based on the hypothesis that a pathogen implicated in a mortality event is present in high amounts, a cut-off was fixed in our QPCR assay to ensure specificity rather than sensitivity. In spite of this, using these protocols we could detect as little as $10^{3}$ bacteria/ $\mathrm{ml}$, allowing a reliable detection of this pathogen.

The production of extracellular enzymes such as proteases by pathogenic Vibrio has been widely observed (Shinoda and Miyoshi, 2011). These proteases, which are often from the family of zinc metalloproteases, are known to be one of the most toxic factors to the host (Delston et al., 2003; Teo et al., 2003; Binesse et al., 2008; Hasegawa et al., 2008; 
Labreuche et al., 2010) particularly for $V$. tubiashii. Hasegawa et al. showed that V. tubiashii 's ECPs were toxic to $C$. gigas larvae, and identified virulence factors in these ECPs: the metalloprotease VtpA and the hemolysin VthA (Hasegawa et al., 2008).

Besides the infection of oysters by french $V$. tubiashii, ECPs from the 07/118 T2 strain produced either from plate agar or from liquid medium were tested for toxicity on oysters by experimental injection.

The stability test showed that $80 \%$ of protease activity is maintained after $48 \mathrm{~h}$ pointing out its potential role in the infection process and the colonization step in particular since metalloproteases are known to degrade the extracellular matrix of a variety of host and tissues even if we cannot exclude the existence of other virulence factors also acting. Interestingly, only ECPs from culture on agar plates (LBSA) showed toxicity. However, differences in protease composition and quantity produced could be suggested, supported by the differential effect of a specific inhibitor such as 1,10-phenanthroline on residual protease activity. This type of difference in bacterial protein composition after culture in liquid or solid medium has been reported previously (Cheung and Fischetti, 1988; McCarter and Silverman, 1990). Culture on solid medium favors biofilm formation and microenvironments that can influence bacterial metabolite production (Cheung and Fischetti, 1988). Bacterial adherence is an important step in local multiplication and infection. Lorian proposed that in vitro systems providing a solid support surface for the growth of bacteria reflect more accurately in vivo conditions (Lorian, 1989). The toxicity of $V$. tubiashii ECPs produced only on agar plates may indicate the importance of adherence in $V$. tubiashii virulence factor production and in consequence in the infection cycle.

It should be noticed that protease activity was only characterized by testing azocasein as a non-specific substrate, as already reported in other studies (Delston et al., 2003; Teo et al., 2003; Labreuche et al., 2006b; Hasegawa et al., 2008), and this was completed using inhibitor assays. A more specific cocktail of inhibitors and substrates should be developed to obtain a more precise composition of the ECPs protease.

The French survey network allows the isolation of dominant strains from haemolymph or tissue samples, but also the conservation of bacteria in cryoprotectant as well as bacterial DNA. With the support of the LNR (National Reference Laboratory for mollusk disease), we were able to screen the different bacterial isolates and also the DNA library, thus avoiding the isolation biases (only the predominant strains isolated on TCBS at $20^{\circ} \mathrm{C}$ are conserved).

A gyrB gene was the target of the screening and primers were designed to amplify DNA from all strains belonging to $V$. tubiashii species. Using this approach, we detected $V$. tubiashii DNA in a strain isolated during 2 episodes of hatchery mortality in 2008. This strain was also isolated in 10 hatchery batches affected by mortalities, 9 from 2007 and 1 from 2004. In conclusion, we have evidence of the presence of high amounts of $V$. tubiashii during 12 episodes of mortality in French hatcheries since 2004. None of the field samples tested revealed for instance the presence of such high amounts of $V$. tubiashii.

\section{Conclusions}

Based on their biochemical and genetic characterization, nine predominant bacterial strains, isolated from a French experimental hatchery/nursery during mortalities events, were classified as a novel group belonging to $V$. tubiashii species. Two reference strains, isolated from diseased abalone and diseased oysters in 2004 and 2007, respectively, were described for this group. The significant pathogenicity of different isolates and the toxicity of the extracellular products of 07/118 T2 were confirmed by experimental challenge. Further 
studies will be required to complete our knowledge on the pathogenic factors secreted by these strains of $V$. tubiashii and their mechanisms of action.

\section{Acknowledgements}

This study was supported by a Ph.D grant from the CNRS and IFREMER for R. MersniAchour (2010-2013). The PRES (Pôle de Recherche et d'Enseignement Supérieur) of Limousin Poitou-Charentes and the FR CNRS 3097 «Fédération de Recherche en Environnement et Développement durable» are acknowledged for financial support through the research project "Caractérisation in vitro des effets de métalloprotéases sur différents types cellulaires de l'huître creuse $C$. gigas».

\section{References}

Aguirre-Guzman, G., Ascencio, F., Saulnier, D., 2005. Pathogenicity of Vibrio penaeicida or white shrimp Litopenaeus vannamei: a cysteine protease-like exotoxin as a virulence factor. Diseases of Aquatic Organisms. 67, 201-207.

Beaz-Hidalgo, R., Balboa, S., Romalde, J. L., Figueras, M. J., 2010. Diversity and pathogenecity of Vibrio species in cultured bivalve molluscs. Environmental Microbiology Reports. 2, 34-43.

Binesse, J., Delsert, C., Saulnier, D., Champomier-Verges, M. C., Zagorec, M., MunierLehmann, I., et al., 2008. Metalloprotease Vsm Is the Major Determinant of Toxicity for Extracellular Products of Vibrio splendidus. Applied and Environmental Microbiology. 74, 7108-7117.

Bower, S. M., Hervio, D., Meyer, G. R., 1997. Infectivity of Mikrocytos mackini, the causative agent of Denman Island disease in Pacific oysters, Crassostrea gigas, to various species of oysters. . Diseases of Aquatic Organism. 29, 111-116.

Cheung, A. L., Fischetti, V. A., 1988. Variation in the expression of cell wall proteins of Staphylococcus aureus grown on solid and liquid media. Infect Immun. 56, 1061-5.

De Decker, S., Normand, J., Saulnier, D., Pernet, F., Castagnet, S., Boudry, P., 2011. Responses of diploid and triploid Pacific oysters Crassostrea gigas to Vibrio infection in relation to their reproductive status. Journal of Invertebrate Pathology. 106, 179191.

De Decker, S., Saulnier, D., 2011. Vibriosis induced by experimental cohabitation in Crassostrea gigas: Evidence of early infection and down-expression of immunerelated genes. Fish \& Shellfish Immunology. 30, 691-699.

Delston, R. B., Kothary, M. H., Shangraw, K. A., Tall, B. D., 2003. Isolation and characterization of a zinc-containing metalloprotease expressed by Vibrio tubiashii. Canadian Journal of Microbiology. 49, 525-529.

Eck, R. V., Dayhoff, M. O., 1966. Atlas of protein sequence and structure. National Biomedical Research Foundation.

Elston, R. A., Hasegawa, H., Humphrey, K. L., Polyak, I. K., Hase, C. C., 2008. Reemergence of Vibrio tubiashii in bivalve shellfish aquaculture: severity, environmental drivers, geographic extent and management. Diseases of Aquatic Organisms. 82, 119-134.

Estes, R. M., Friedman, C. S., Elston, R. A., Herwig, R. P., 2004. Pathogenicity testing of shellfish hatchery bacterial isolates on Pacific oyster Crassostrea gigas larvae. Diseases of Aquatic Organisms. 58, 223-30.

Ezaki, T., Hashimoto, Y., Yabuuchi, E., 1989. Fluorometric deoxyribonucleic aciddeoxyribonucleic acid hybridization in microdilution wells as an alternative to membrane filter hybridization in which radioisotopes are used to determine genetic 
relatedness among bacterial strains. International Journal of Systematic Bacteriology. 39, 224-229.

Felsenstein, J., 1985. Confidence limits on phylogenies: an approach using the boostrap. Evolution. 39, 783-791.

Gagnaire, B., Gay, M., Huvet, A., Daniel, J. Y., Saulnier, D., Renault, T., 2007. Combination of a pesticide exposure and a bacterial challenge: in vivo effects on immune response of Pacific oyster, Crassostrea gigas (Thunberg). Aquatic toxicology. 84, 92-102.

Garnier, M., Labreuche, Y., Garcia, C., Robert, M., Nicolas, J. L., 2007. Evidence for the involvment of pathogenic bacteria in summer mortalities of the Pacific oyster Crassostrea gigas. Microbial Ecology. 53, 173-186.

Garnier, M., Labreuche, Y., Nicolas, J. L., 2008. Molecular and phenotypic characterization of Vibrio aestuarianus subsp. francensis subsp. nov., a pathogen of the oyster Crassostrea gigas. Systematic and Applied Microbiology. 31, 358-65.

Gay, M., Berthe, F. C., Le Roux, F., 2004. Screening of Vibrio isolates to develop an experimental infection model in the Pacific oyster Crassostrea gigas. Diseases of Aquatic Organisms. 59, 49-56.

Gharaibeh, D. N., Hasegawa, H., Hase, C. C., 2009. Development of a quantitative real-time PCR assay for detection of Vibrio tubiashii targeting the metalloprotease gene. Journal of Microbiological Methods. 76, 262-268.

Gomez-Gil, B., Soto-Rodriguez, S., Garcia-Gasca, A., Roque, A., Vazquez-Juarez, R., Thompson, F. L., et al., 2004. Molecular identification of Vibrio harveyi-related isolates associated with diseased aquatic organisms. Microbiology. 150, 1769-77.

Hada, H. S., West, P. A., Lee, J. V., Stemmler, J., Colwell, R. R., 1984. Vibrio tubiashii sp. nov. a pathogen of bivalve mollusks. International Journal of Systematic Bacteriology. 34, 1-4.

Hasegawa, H., Lind, E. J., Boin, M. A., Hase, C. C., 2008. The extracellular metalloprotease of Vibrio tubiashii is a major virulence factor for Pacific oyster (Crassostrea gigas) larvae. Applied and Environmental Microbiology. 74, 4101-4110.

Hoffmann, M., Monday, S. r., Fischer, M., Brown, E. w., 2012. Genetic and phylogenetic evidence for misidentification of Vibrio species within the Harveyi clade. Letters in applied Microbiology. 54, 160-165.

Jeffries, V. E., 1982. Three Vibrio strains pathogenic to larvae of Crassostrea gigas and Ostrea edulis. Aquaculture. 29, 201-226.

Kothary, M. H., Delston, R. B., Curtis, S. K., McCardell, B. A., Tall, B. D., 2001. Purification and Characterization of a Vulnificolysin-Like Cytolysin Produced by Vibrio tubiashii. Applied and Environmental Microbiology. 67, 3707-3711.

Labreuche, Y., Lambert, C., Soudant, P., Boulo, V., Huvet, A., Nicolas, J.-L., 2006a. Cellular and molecular hemocyte responses of the Pacific oyster, Crassostrea gigas, following bacterial infection with Vibrio aestuarianus strain 01/32. Microbes and Infection. 8, 2715-2724.

Labreuche, Y., Le Roux, F., Henry, J., Zatylny, C., Huvet, A., Lambert, C., et al., 2010. Vibrio aestuarianus zinc metalloprotease causes lethality in the Pacific oyster Crassostrea gigas and impairs the host cellular immune defenses. Fish \& Shellfish Immunology. 29, 753-758.

Labreuche, Y., Soudant, P., Goncalves, M., Lambert, C., Nicolas, J., 2006b. Effects of extracellular products from the pathogenic Vibrio aestuarianus strain 01/32 on lethality and cellular immune responses of the oyster Crassostrea gigas. Developmental \& Comparative Immunology. 30, 367-379.

Lacoste, A., Jalabert, F., Malham, S., Cueff, A., Gélébart, F., Cordevant, C., et al., 2001. A Vibrio splendidus strain is associated with summer mortality of juvenile oysters Crassostrea gigas in the Bay of Morlaix (North Brittany, France). Diseases of Aquatic Organisms. 46, 139-145.

Le Roux, F., Gay, M., Lambert, C., Waechter, M., Poubalanne, S., Chollet, B., et al., 2002. Comparative analysis of Vibrio splendidus-related strains isolated during Crassostrea gigas mortality events. Aquatic Living Resources. 15, 251-258. 
Liu, P. V., 1957. Survey of hemolysin production among species of Aeromonas hydrophila with reduced virulence for fish. Infection and Immunity. 74, 718-727.

Lorian, V., 1989. In vitro simulation of in vivo conditions: physical state of the culture medium. Journal of Clinical Microbiology. 27, 2403-6.

McCarter, L., Silverman, M., 1990. Surface-induced swarmer cell differentiation of Vibrio parahaemolyticus. Molecular Microbiology. 4, 1057-62.

Meyers, J. A., Burreson, E. M., Barber, B. J., Mann, R., 1991. Susceptibility of diploid and triploid Pacific oysters, Crassostrea gigas (Thunberg, 1793), and eastern oysters, Crassostrea virginica (Gmelin, 1791), to Perkinsus marinus. Journal of Shellfish Research. 10, 433-437.

Prado, S., Romalde, J., Montes, J., Barja, J. L., 2005. Pathogenic bacteria isolated from disease outbreaks in shellfish hatcheries. First description of Vibrio neptunius as an oyster pathogen Diseases of Aquatic Organisms. 67, 209-215.

Renault, T., Le Deuff, R.-M., Cochennec, N., Maffart, P., 1994. Herpesviruses associated with mortalities among Pacific oyster, Crassostrea gigas, in France-Comparative study. Revue Médicale Vétérinaire. 145, 735-742.

Romalde, J. L., Barja, J. L., 2010. Bacteria in molluscs: good and bad guys. Current Research, Technology and Education Topics in Applied Microbiology and Microbial Biotechnology. 1, 136-147.

Saitou, N., Nei, M., 1987. The neighbor-joining method: a new method for reconstructing phylogenetic trees. Molecular Biology and Evolution. 4, 406-25.

Samain, J. F., Dégremont, L., Soletchnik, P., Haure, J., Bédier, E., Ropert, M., et al., 2007. Genetically based resistance to summer mortality in the Pacific oyster (Crassostrea gigas) and its relationship with physiological, immunological characteristics and infection processes. Aquaculture. 268, 227-243.

Saulnier, D., De Decker, S., Haffner, P., 2009. Real-time PCR assay for rapid detection and quantification of Vibrio aestuarianus in oyster and seawater: A useful tool for epidemiologic studies. Journal of Microbiological Methods. 77, 191-197.

Saulnier, D., De Decker, S., Haffner, P., Cobret, L., Robert, M., Garcia, C., 2010. A largescale epidemiological study to identify bacteria pathogenic to pacific oyster Crassostrea gigas and correlation between virulence and metalloprotease-like activity. Microbial Ecology. 59, 787-798.

Saulnier, D., Haffner, P., Goarant, C., Levy, P., Ansquer, D., 2000. Experimental infection models for shrimp vibriosis studies: a review. Aquaculture. 191, 133-144.

Segarra, A., Pepin, J. F., Arzul, I., Morga, B., Faury, N., Renault, T., 2010. Detection and description of a particular Ostreid herpesvirus 1 genotype associated with massive mortality outbreaks of Pacific oysters, Crassostrea gigas, in France in 2008. Virus Research. 153, 92-9.

Shinoda, S., Miyoshi, S., 2011. Proteases produced by vibrios. Biocontrol Sci. 16, 1-11.

Sugumar, G., Nakai, T., Hirata, Y., Matsubara, D., Muroga, K., 1998. Vibrio splendidus biovar II as the causative agent of bacillary necrosis of Japanese oyster Crassostrea gigas larvae Diseases of Aquatic Organisms. 33, 111-118.

Teo, J. W. P., Zhang, L.-H., Poh, C. L., 2003. Cloning and characterization of a metalloprotease from Vibrio harveyi strain AP6. Gene. 303, 147-156.

Thompson, F. L., Gevers, D., Thompson, C. C., Dawyndt, P., Naser, N., Hoste, B., et al., 2005. Phylogeny and molecular identification of vibrios on the basis of multilocus sequence analysis. Applied and Environmental Microbiology. 71, 5107-5115.

Thompson, F. L., Gomez-Gil, B., Vasconcelos, A. T., Sawabe, T., 2007. Multilocus sequence analysis reveals that Vibrio harveyi and $V$. campbellii are distinct species. Appl Environmental Microbiology. 73, 4279-85.

Travers, M. A., Barbou, A., Le Goïc, N., Huchette, S., Paillard, C., Koken, M., 2008. Construction of a stable GFP-tagged Vibrio harveyi strain for bacterial dynamics analysis of abalone infection. FEMS Microbiol Lett. 289, 34-40.

Travers, M. A., Le Bouffant, R., Friedman, C. S., Buzin, F., Cougard, B., Huchette, S., et al., 2009. Pathogenic Vibrio harveyi, in contrast to non-pathogenic strains, intervenes 
with the p38 MAPK pathway to avoid an abalone haemocyte immune response. Journal of Cellular Biochemistry. 106, 152-160.

Tubiash, H. S., Chanley, P. E., Leifson, E., 1965. Bacillary necrosis, a disease of larval and juvenile bivalve mollusks I. Etiology and epizootiology. Journal of Bacteriology. 90, 1036-1044.

Tubiash, H. S., Colwell, R. R., Sakazaki, R., 1970. Marine vibrios associated with bacillary necrosis, a disease of larval and juvenile bivalve mollusks. Journal of Bacteriology. 103, 272-273.

Tun, K. L., Itoh, N., Shimizu, Y., Yamanoi, H., Yoshinaga, T., Ogawa, K., 2008. Pathogenicity of the protozoan parasite Marteilioides chungmuensis in the Pacific oyster Crassostrea gigas. International Journal for Parasitology. 38, 211-217.

Wayne, L. G., Brenner, D. J., Colwell, R. R., Grimont, P. A. D., Kandler, O., Krichevsky, M. I., et al., 1987. Report of the Ad Hoc Committee on Reconciliation of Approaches to Bacterial Systematics. International Journal of Systematic Bacteriology. 37, 463-464.

Williams, H. R., Macey, B. M., Burnett, L. E., Burnett, K. G., 2009. Differential localization and bacteriostasis of Vibrio campbellii among tissues of the Eastern oyster, Crassostrea virginica. Developmental and Comparative Immunology. 33, 592-600.

Wilson, K., Preparation of genomic DNA from bacteria. In: F. M. Ausubel, et al., Eds.), Current protocols in molecular biology. Greene Publishing and Wiley Interscience, New York, 1987, pp. 2.4.1-2.4.5. 


\section{Figures}

Figure 1: Neighbor-joining phylogenetic tree showing the phylogenetic position of $V$. tubiashii strains, based on concatenated 16S rDNA, ftsZ, pyrH, recA and topA gene sequences (2307 bp). Phylogenetic analyses were conducted in MEGA4. The optimal tree with the sum of branch length $=2.23671430$ is shown. The percentage of replicate trees in which the associated taxa clustered together in the bootstrap test (1000 replicates) is shown next to the branches. Nodes without a number are of low significance $(<50 \%)$.

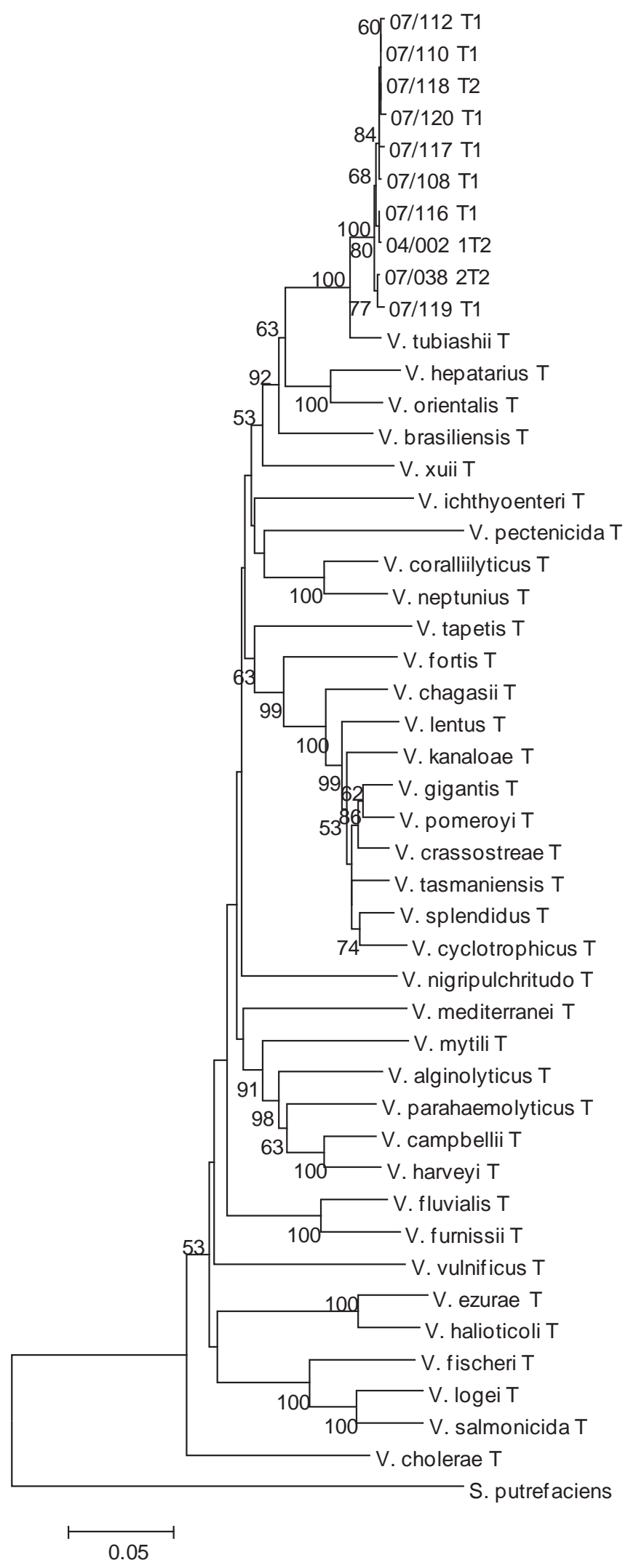


Figure 2: Neighbor-joining phylogenetic tree showing the phylogenetic position of $V$. tubiashii strains, based on recA sequences (357 bp). Phylogenetic analyses were conducted in MEGA4. The optimal tree with the sum of branch length $=1.103893013$ is shown. The percentage of replicate trees in which the associated taxa clustered together in the bootstrap test (1000 replicates) is shown next to the branches. Nodes without a number are of low significance $(<50 \%)$.

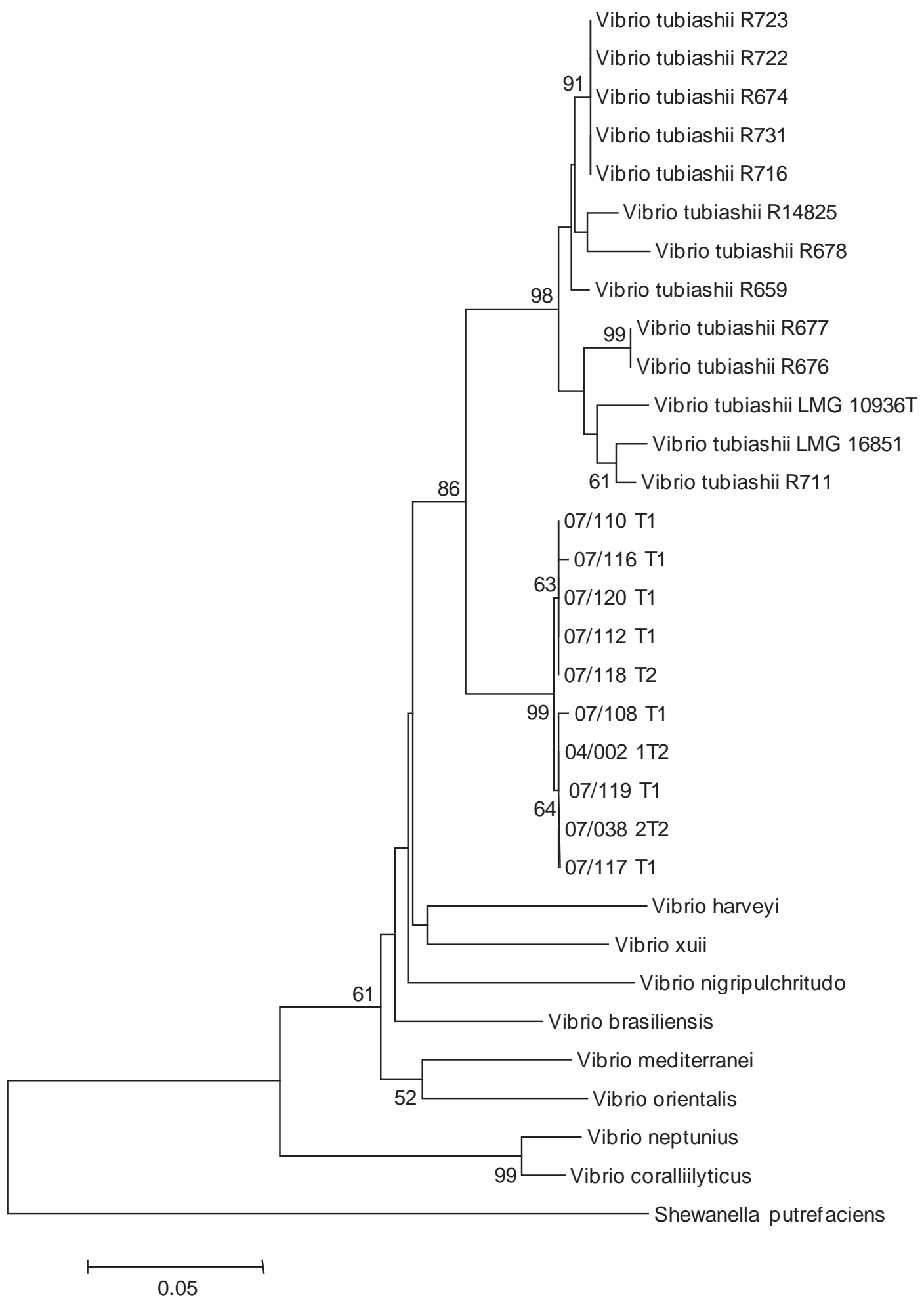


Figure 3: Cumulative mortalities recorded during experimental infections performed on adult oysters. Bacterial strains were grown for $24 \mathrm{~h}$ in Zobell broth before resuspension into artificial and sterile seawater (SASW) and $\mathrm{DO}_{600}$ adjustment to $1.100 \mu$ l of bacterial suspension were injected into anesthetized oysters. The control corresponds to the injection in similar conditions of sterile SASW $(\mathbf{A})$ or injection of non virulent $V$. tasmaniensis LMG20012 $(x)$ adjusted to $\mathrm{DO}_{600}=1$. Seven strains of $V$. tubiashii were tested $(07 / 0382 \mathrm{~T} 2$, 07/110 T1, 07/112 T1, 07/118 T2, 07/119 T1, 07/120 T1 and 04/002 1T2). Standard deviations are represented by bars ( $\mathrm{n}=3$ biological replicates).

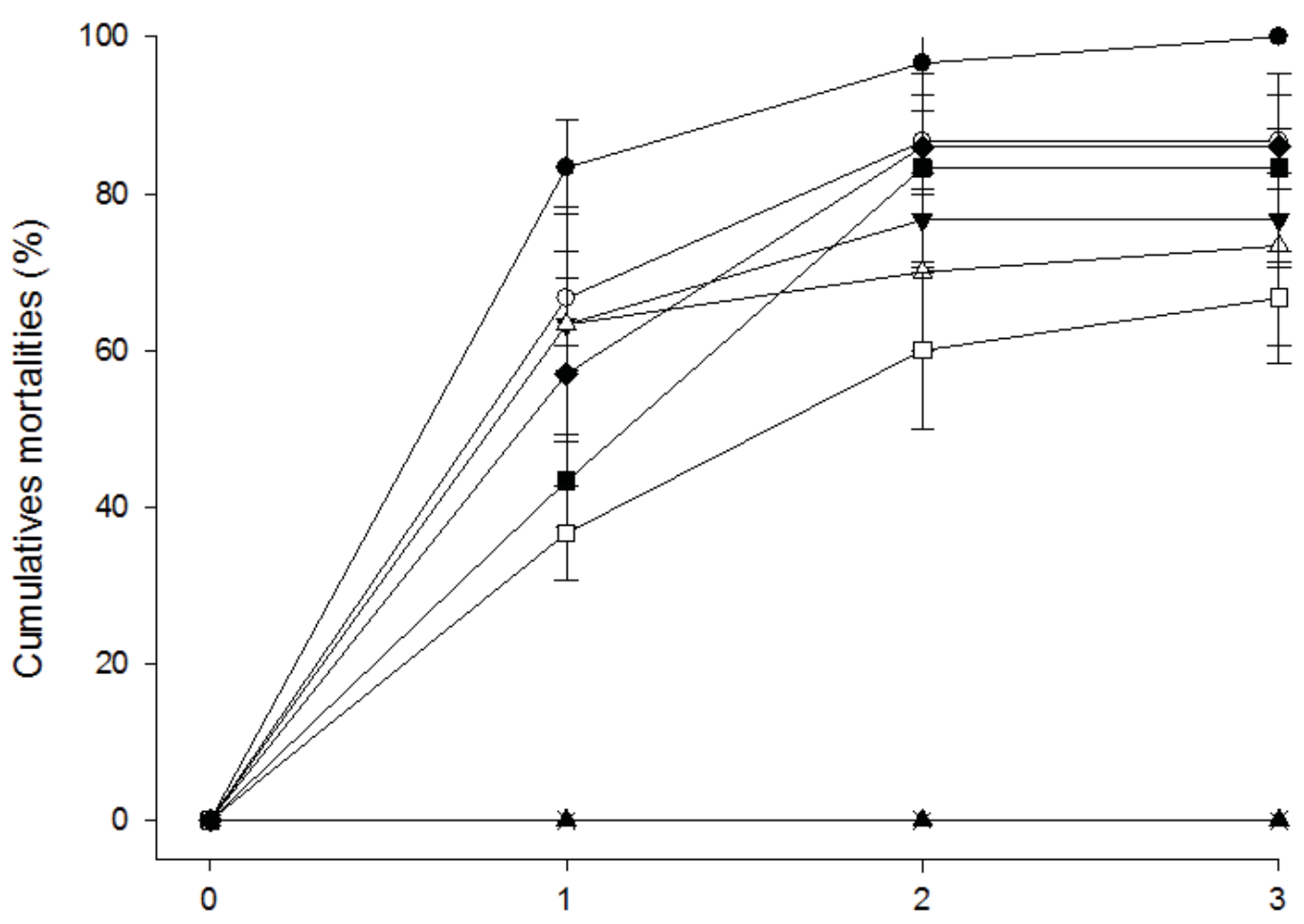

Days

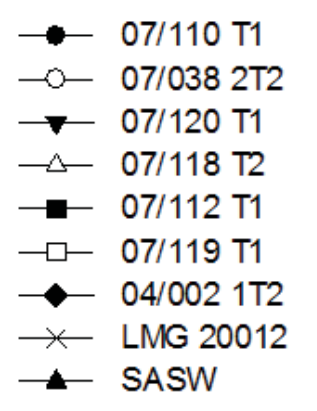


Figure 4: (A) Cumulative mortalities of juvenile oysters following intramuscular injection of $V$. tubiashii (07/118 T2= LMG 27884= CECT 8426) ECPs produced on LBSA and LBS medium and in vitro stability of protease activity (azocaseinase activity).

The primary axis corresponds to cumulative mortalities recorded during experimental infections performed on juvenile oysters after injection of 07/118 T2 ECPs produced in LBS and on LBSA medium (solid curves). $100 \mu \mathrm{l}$ of ECPs (5 $\mathrm{g} \mathrm{g} \mathrm{g}^{-1}$ of proteins) were injected into anesthetized oysters. The control corresponds to the injection in similar condition of artificial and sterile seawater (SASW) and Tris- $\mathrm{HCl}$ buffer $(50 \mathrm{mM} \mathrm{pH} 8)$.

The secondary axis corresponds to the stability of protease activity measured in vitro (dashed line curve). $100 \mu \mathrm{l}$ of $07 / 118 \mathrm{~T} 2 \mathrm{ECPs}$ produced on LBSA were incubated at $22^{\circ} \mathrm{C}$ for two days. The azocaseinase activity (after $24 \mathrm{~h}$ and $48 \mathrm{~h}$ ) was measured using an azocasein assay. Standard deviations are represented by bars ( $\mathrm{n}=2$ biological replicates).

(B) Effect of one metalloprotease inhibitor on azocaseinase activity of 07/118 T2 ECPs produced on LBSA and LBS medium.

${ }^{a}$ Final concentration of the inhibitor in the assay mixture.

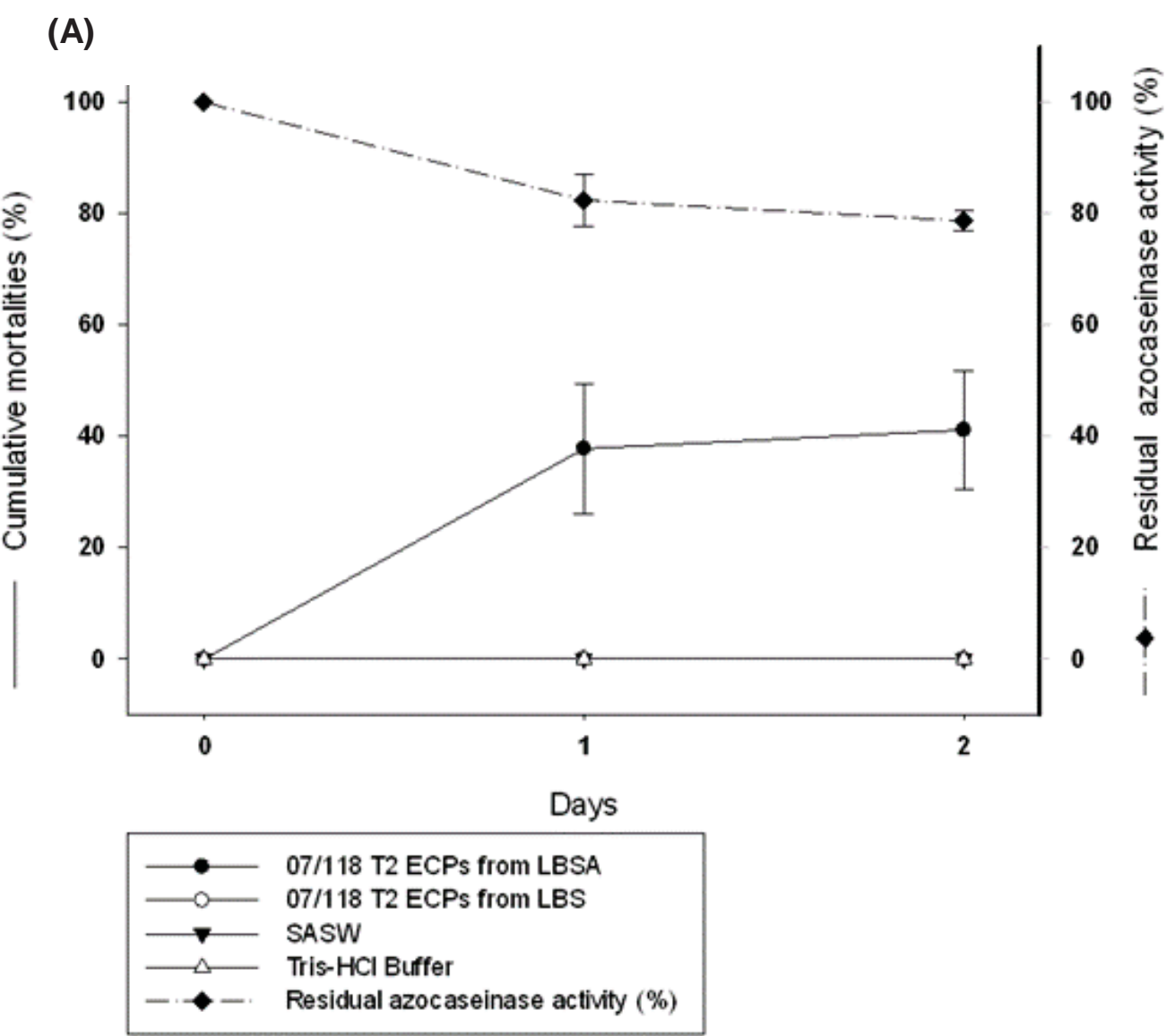

(B) 
Table 1: Bacterial strains used and their sources, as well as QPCR gyrB assays for the different Vibrio species. QPCR were performed twice on $5 \mu \mathrm{l}$ of boiled bacteria or on $25 \mathrm{ng}$ of genomic DNA.

\section{Strains References Source and date of isolation}

04/002 1T2 (Saulnier et Diseased spat abalone (Haliotis tuberculata), Cotentin, France, al., 2010) January 2004

07/038 2T2 (Saulnier et

Diseased diploid spat oysters, (Crassostrea gigas), Ronce les al., 2010)

Bains, France, June 2007

07/108 T1 Present study

Diseased diploid spat oysters, (Crassostrea gigas), Ronce les Bains, France, August 2007

(Saulnier et
al., 2010)

Diseased diploid spat oysters, (Crassostrea gigas), Ronce les

07/112 T1 Present study

Bains, France, August 2007

07/116 T1 Present study

Diseased diploid spat oysters, (Crassostrea gigas), Ronce les

Bains, France, August 2007

$07 / 116$ T1 Present study

Diseased triploid spat oysters, (Crassostrea gigas), Ronce les

Bains, France, August 2007
07/117 T1 (Saulnier et al., 2010)

Diseased triploid spat oysters, (Crassostrea gigas), Ronce les

07/118 T2 Present study

Bains, France, August 2007

$07 / 118 \mathrm{~T} 2$ Present study

Diseased diploid spat oysters, (Crassostrea gigas), Ronce les

Bains, France, August 2007

$\begin{aligned} & \text { 07/119 T1 } \text { (Saulnier et } \\ & \text { al., 2010) }\end{aligned}$

Diseased diploid spat oysters, (Crassostrea gigas), Ronce les

07/120 T1 Present study

Bains, France, August 2007

Diseased diploid spat oysters, (Crassostrea gigas), Ronce les Bains, France, August 2007
V. tubiashii
LMG 10936T
LMG 11229
LMG 16851
V. brasiliensis
LMG 20546T
V. coralliilyticus
DSMZ 19607T
$V$. hepatarius
LMG 20362T

\section{V. neptunius}
LMG 20536T

\section{$V$. nereis}
LMG 3895T
V. orientalis
LMG 7897T
V. tasmaniensis

Hardclam (Mercenaria mercenaria), moribund larvae, Milford, USA

Moribund juvenile oyster (Crassostrea virginica), Milford, USA

Sea bream, Greece

Bivalve larvae (Nodipecten nodosus), Brazil

Diseased coral (Pocillopora damicornis), Indian Ocean near Zanzibar

Litopenaeus vannamei, Manglaralto, Ecuador

Bivalve larvae (Nodipecten nodosus), Brazil

Seawater enriched with propanol, Hawaii, United States

Seawater, Yello sea, China 
LMG 20012T

Atlantic salmon (Salmosalar), Tasmania Australia

VI

V. xuii

DSMZ 17185T

Shrimp culture water, China

ND: not done 
Table 2: DNA-DNA hybridizations

The DNA-DNA relatedness percentages are the mean of minimum 6 hybridization assays. The values given between brackets are the differences between the reciprocal values.

\begin{tabular}{c||cccc} 
& & & & \\
& & & & \\
& Vibrio sp. & Vibrio sp. & V. tubiashii & V. hepatarius \\
& 04/002 1T2 & 07/118 T2 & LMG 10936T & LMG 20362T \\
& LMG 27885 & & \\
\hline $\begin{array}{c}\text { Vibrio sp. } \\
\text { 04/002 1T2 }\end{array}$ & 100 & & \\
LMG 27885 & & & \\
\hline $\begin{array}{c}\text { Vibrio sp. } \\
\text { 07/118 T2 }\end{array}$ & $86(11)$ & 100 & \\
LMG 27884 & & & \\
\hline $\begin{array}{l}\text { V. tubiashii } \\
\text { LMG 10936T }\end{array}$ & $69(12)$ & $69(13)$ & \\
\hline $\begin{array}{l}\text { V. hepatarius } \\
\text { LMG 20362T }\end{array}$ & $21(4)$ & $22(3)$ & $24(10)$
\end{tabular}


Table 3: Phenotypic characteristics of Vibrio sp. isolated from C. gigas

Traits were determined using API20E, API20NE and API50CH, and standard growth assays under various culture conditions ( $\mathrm{NaCl}$, temperature, and presence of an antibiotic). Symbols are: +: positive; -: negative. For the ten French isolates of $V$. tubiashii tested (column 1 ) and for the three V. tubiashii (column 2: LMG 10936T, LMG 11229 and LMG 16851), dominant traits are indicated and traits which differ among isolates are given in parentheses.

UB30: Flumequine $30 \mu \mathrm{g}$, E30: Erythromycin $30 \mu \mathrm{g}$, C30: Chloramphenicol $30 \mu \mathrm{g}$, CN30: Gentamicin $30 \mu \mathrm{g}$, K30: Kanamycin $30 \mu \mathrm{g}$, TE30: Tetracycline $30 \mu \mathrm{g}$, SXT25: Sulphamethoxazole/trimethoprim 19:1 $25 \mu \mathrm{g}$, S25: Streptomycin $25 \mu \mathrm{g}$, S3: Sulphonamides $300 \mu \mathrm{g}$, W5: Trimethoprim $5 \mu \mathrm{g}, 0129 / 150$ and O129/10: vibrio static agent, pteridine $150 \mu \mathrm{g}$ and $10 \mu \mathrm{g}$, respectively, P10: Penicillin $10 \mathrm{UI}(6 \mu \mathrm{g})$, AMP10: Ampicillin $10 \mu \mathrm{g}$

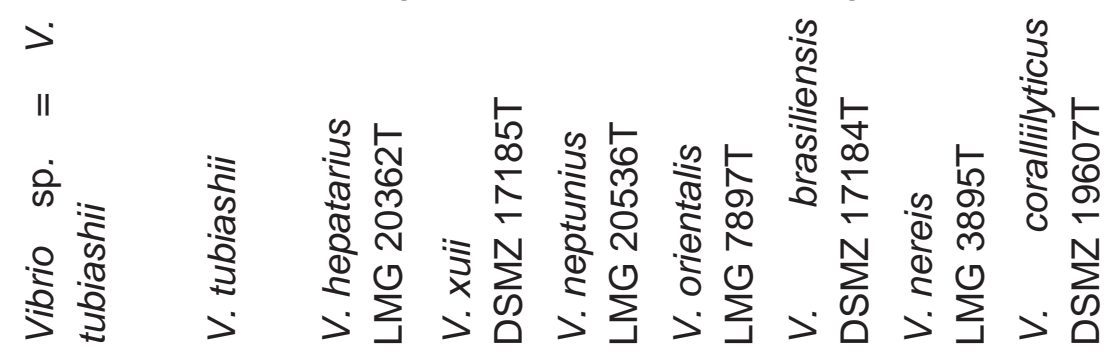

Growth in $\mathrm{NaCl}$ at

$$
\begin{aligned}
& 8 \%(w / v) \\
& 10 \%(w / v)
\end{aligned}
$$

Growth at

$40^{\circ} \mathrm{C}$

Antibiotic sensitivity

UB30

$\mathrm{E} 30, \mathrm{C} 30, \mathrm{CN} 30$

K30, TE30, SXT25, S25,

S3, W5, O129/150,

O129/10

P10, AMP10

Acid production from

L-arabinose

D-ribose

Mannitol

Salicin

Cellobiose

Melibiose

Citrate

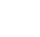




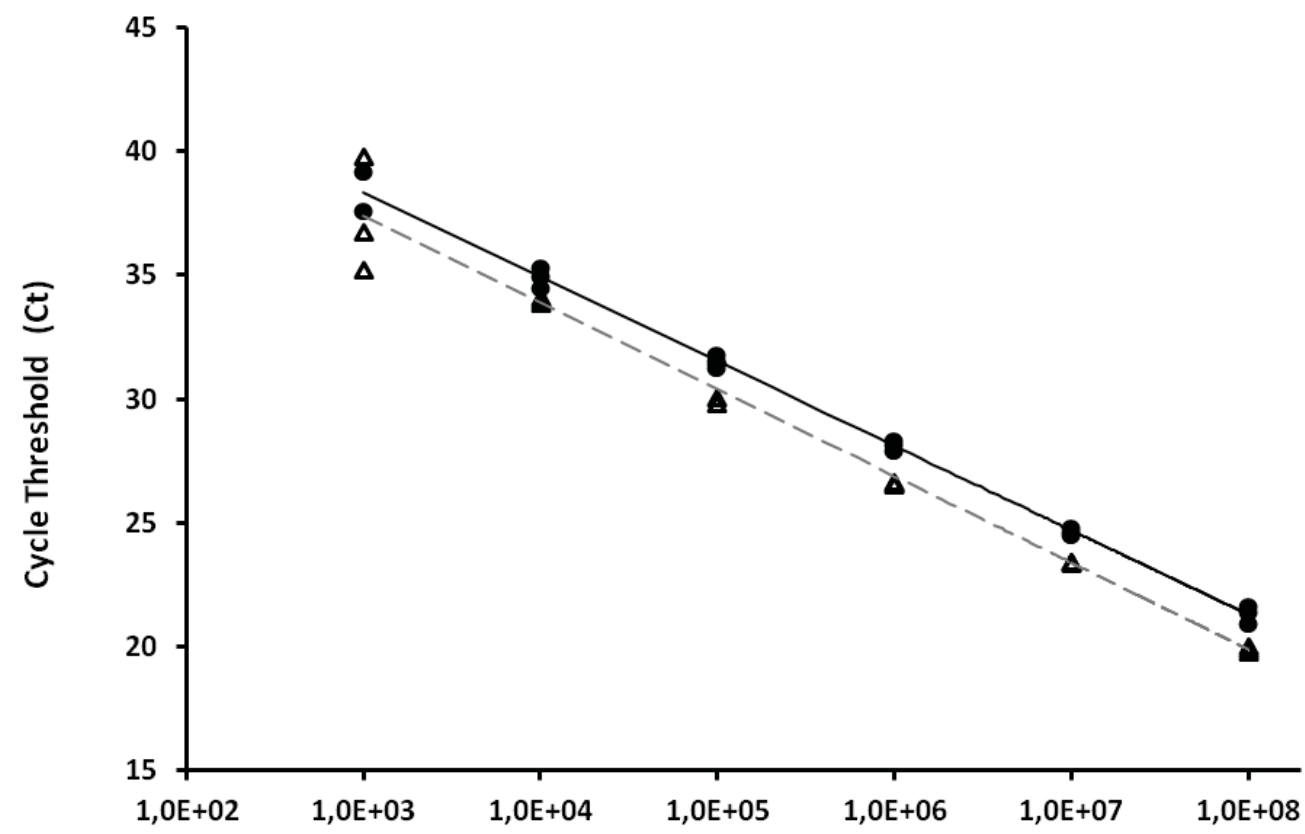

- V. tubiashii type strain

Log cell numbers of $V$. tubiashii $\mathrm{ml}^{-1}$

$\Delta \quad$ v. tubiashii French isolates

\section{Supplementary Fig. S1. QPCR gyrB diagnostic tool}

Standard curves for $V$. tubiashii type strain and French isolates using QPCR in 10 fold dilutions of genomic DNA. Standard curves were generated by plotting the threshold cycle (Ct) versus the log cell number of bacteria value. Each plot corresponds to the individual values of $\mathrm{Ct}$ obtained from a representative experiment of all experiments performed independently. The linear regression represented by the solid line, was obtained by collectively treating all the data of $V$. tubiashii with an $\mathrm{r}^{2}$ of 0.996 and a PCR reaction efficacy of $96.3 \%$. The linear regression represented by the dotted line was obtained by collectively treating all the data of $V$. tubiashii with an $r^{2}$ of 0.988 and a PCR reaction efficacy of $99.2 \%$. 
Supplementary Table 1: Primers used for DNA sequencing and QPCR development

\begin{tabular}{|c|c|c|c|c|c|}
\hline Gene & Primers & Sequence & $\begin{array}{c}\text { Annealing } \\
\text { temperature }\end{array}$ & $\begin{array}{l}\text { Amplicon } \\
\text { size (bp) }\end{array}$ & Application \\
\hline $\begin{array}{l}16 \mathrm{~s} \\
\text { rRNA }\end{array}$ & $\begin{array}{l}\text { SAdir } \\
\text { S17rev }\end{array}$ & $\begin{array}{l}\text { AGAGTTTGATCATGGCTCAGA } \\
\text { GTTACCTTGTTACGACTT }\end{array}$ & $50^{\circ} \mathrm{C}$ & 1500 & \\
\hline$f t s Z$ & $\begin{array}{l}\text { VftsZ75F } \\
\text { VftsZ800R }\end{array}$ & $\begin{array}{l}\text { GCTGTTGAACACATGGTACG } \\
\text { GCACCAGCAAGATCGATATC }\end{array}$ & $50^{\circ} \mathrm{C}$ & 750 & \\
\hline pyrH & $\begin{array}{l}\text { VpyrH80F } \\
\text { VpyrH530R }\end{array}$ & $\begin{array}{l}\text { GATCGTATGGCTCAAGAAG } \\
\text { TAGGCATTTTGTGGTCACG }\end{array}$ & $50^{\circ} \mathrm{C}$ & 450 & $\begin{array}{c}\text { PCR } \\
\text { amplification } \\
\text { and }\end{array}$ \\
\hline topA & $\begin{array}{l}\text { VtopA400F } \\
\text { VtopA1200R }\end{array}$ & $\begin{array}{l}\text { GAGATCATCGGTGGTGATG } \\
\text { GAAGGACGAATCGCTTCGTG }\end{array}$ & $50^{\circ} \mathrm{C}$ & 800 & $\begin{array}{l}\text { sequencing } \\
\text { (Thompson } \\
\text { et al., 2007) }\end{array}$ \\
\hline recA & $\begin{array}{l}\text { VrecA130F } \\
\text { VrecA720R }\end{array}$ & $\begin{array}{l}\text { GTCTACCAATGGGTCGTATC } \\
\text { GCCATTGTAGCTGTACCAAG }\end{array}$ & $50^{\circ} \mathrm{C}$ & 600 & \\
\hline gyrB & $\begin{array}{l}\text { VgyrB274F } \\
\text { VgyrB1171R }\end{array}$ & $\begin{array}{c}\text { GAAGTTATCATGACGGTACTTC } \\
\text { CCTTTACGACGAGTCATTTC }\end{array}$ & $55^{\circ} \mathrm{C}$ & 900 & \\
\hline gyrB & $\begin{array}{c}\text { gyrB94F } \\
\text { gyrB296R } \\
\text { gyrBprobe203 }\end{array}$ & $\begin{array}{l}\text { TTGGTGAATCTGAGCAAACG } \\
\text { CGCTTGGATACCACCTTCAT } \\
\text { TCTGGCCAAGTGAAGAGACA } \\
\text { (5'Rox - 3'BHQ-2) }\end{array}$ & $60^{\circ} \mathrm{C}$ & 202 & $\begin{array}{c}\text { QPCR } \\
\text { diagnostic } \\
\text { (this study) }\end{array}$ \\
\hline
\end{tabular}


Supplementary Table 2: QPCR diagnostics (detection of V. tubiashii with gyrB taqman assay) performed on DNA extracts from oyster tissues sampled during mortality events (REPAMO network). QPCR were performed on $25 \mathrm{ng}$ of total DNA and considered as positive when Ct values were greater than 36. Batch names (sampling year / sampling number) and origin are indicated in the first columns.

$\begin{array}{ccc}\text { Batch } & \text { Origin } & \text { Number of positive samples } \\ (V . \text { tubiashii })\end{array}$

\begin{tabular}{|c|c|c|}
\hline $2008 / 011$ & Hatchery/nursery & $0 / 2$ \\
\hline $2008 / 062$ & Hatchery/nursery & $0 / 20$ \\
\hline $2008 / 082$ & Hatchery/nursery & $0 / 4$ \\
\hline $2008 / 104$ & Hatchery/nursery & $1 / 1$ \\
\hline $2008 / 105$ & Hatchery/nursery & $0 / 5$ \\
\hline $2008 / 110$ & Hatchery/nursery & $0 / 5$ \\
\hline $2008 / 132$ & Hatchery/nursery & $1 / 6$ \\
\hline $2008 / 139$ & Hatchery/nursery & $0 / 6$ \\
\hline $2008 / 165$ & Hatchery/nursery & $0 / 3$ \\
\hline $2008 / 166$ & Hatchery/nursery & $0 / 3$ \\
\hline $2009 / 051$ & Hatchery/nursery & $0 / 3$ \\
\hline $2009 / 052$ & Hatchery/nursery & $0 / 3$ \\
\hline $2009 / 066$ & Hatchery/nursery & $0 / 6$ \\
\hline $2009 / 067$ & Hatchery/nursery & $0 / 2$ \\
\hline 2009/109 & Hatchery/nursery & $0 / 11$ \\
\hline $2009 / 143$ & Hatchery/nursery & $0 / 2$ \\
\hline $2010 / 080$ & Hatchery/nursery & $0 / 1$ \\
\hline $2010 / 125$ & Hatchery/nursery & $0 / 2$ \\
\hline 2011/009 & Hatchery/nursery & $0 / 4$ \\
\hline $2011 / 010$ & Hatchery/nursery & $0 / 4$ \\
\hline $2011 / 176$ & Hatchery/nursery & $0 / 6$ \\
\hline $2008 / 076$ & Field - juveniles $3 n$ & $0 / 10$ \\
\hline $2008 / 077$ & Field - juveniles $3 n$ & $0 / 10$ \\
\hline $2008 / 075$ & Field - juveniles $3 n$ & $0 / 10$ \\
\hline $2008 / 102$ & Field - adults $2 n$ & $0 / 10$ \\
\hline $2008 / 080$ & Field - spat 3n & $0 / 10$ \\
\hline $2008 / 081$ & Field - juveniles $2 n$ & $0 / 10$ \\
\hline $2008 / 090$ & Field - juveniles $3 n$ & $0 / 10$ \\
\hline $2008 / 092$ & Field - spat $2 n$ & $0 / 10$ \\
\hline $2008 / 093$ & Field - spat $3 n$ & $0 / 10$ \\
\hline
\end{tabular}




\begin{tabular}{|c|c|c|}
\hline 2008/098 & Field - juveniles 2n & $0 / 10$ \\
\hline $2008 / 097$ & Field - juveniles 2n & $0 / 10$ \\
\hline $2008 / 085$ & Field - spat 3n & $0 / 10$ \\
\hline $2008 / 086$ & Field - juveniles $2 n$ & $0 / 10$ \\
\hline $2008 / 087$ & Field - spat 3n & $0 / 10$ \\
\hline $2008 / 088$ & Field - spat $2 n$ & $0 / 10$ \\
\hline $2008 / 096$ & Field - juveniles 3n & $0 / 10$ \\
\hline $2008 / 089$ & Field - spat $2 n$ & $0 / 10$ \\
\hline $2008 / 091$ & Field - juveniles $3 n$ & $0 / 10$ \\
\hline $2008 / 074$ & Field - juveniles $3 n$ & $0 / 10$ \\
\hline $2008 / 079$ & Field - spat $2 n$ & $0 / 10$ \\
\hline $2008 / 083$ & Field - juveniles 2n & $0 / 10$ \\
\hline $2008 / 084$ & Field - spat 2n & $0 / 10$ \\
\hline $2008 / 108$ & Field - spat $2 n$ & $0 / 10$ \\
\hline $2012 / 080$ & Field - adults & $0 / 10$ \\
\hline $2012 / 112$ & Field - adults & $0 / 10$ \\
\hline $2012 / 067$ & Field - adults & $0 / 10$ \\
\hline $2012 / 099$ & Field - adults & $0 / 10$ \\
\hline $2012 / 114$ & Field - adults & $0 / 10$ \\
\hline
\end{tabular}




\section{Supplementary Table 3: Genbank accession numbers}

\begin{tabular}{|c|c|c|c|c|c|c|}
\hline & 16s rDNA & ftsZ & pyrH & topA & recA & gyrB \\
\hline V. alginolyticus LMG 4409T & X74690 & EF027344 & JN408273 & DQ907472 & AJ842373 & \\
\hline V. brasiliensis LMG20546T & AJ316172 & DQ907335 & HQ452398 & DQ907473 & HM771379 & HM771364 \\
\hline V. campbelli LMG11216T & X56575 & DQ907337 & EF596641 & DQ907475 & EF596670 & \\
\hline V. chagasii LMG21353T & AJ316199 & DQ996590 & EU118252 & DQ481649 & AJ580874 & \\
\hline V. cholerae CECT $514 \mathrm{~T}$ & X74695 & HE805627 & FM202582 & HE805631 & FM204835 & \\
\hline V. coralliilyticus LMG20984T & AJ440005 & DQ907341 & GU266292 & EF114213 & JN039156 & AB298210 \\
\hline V. crassostreae LMG22240T & AJ582808 & DQ481624 & EU871948 & DQ481650 & EU541594 & \\
\hline V. cyclitrophicus LMG21359T & U57919 & DQ481625 & EU871958 & DQ481651 & AJ842405 & \\
\hline V. ezurae LMG19970T & AY426980 & DQ907343 & EU871949 & DQ907481 & AJ842413 & \\
\hline V. fisheri LMG4414T & X70640 & DQ907344 & EU185914 & DQ907482 & AJ842417 & \\
\hline V. fluvialis LMG7894T & X74703 & DQ907345 & JN426808 & DQ907483 & AJ580892 & \\
\hline V. fortisLMG $21557 \mathrm{~T}$ & AJ514916 & DQ907346 & EU251629 & DQ907484 & AJ842422 & \\
\hline V. furnisii LMG 7910T & X74704 & EF027345 & JF316672 & DQ907485 & AJ842427 & \\
\hline V. gigantis LMG22741T & AJ582810 & DQ481629 & EU871951 & DQ481655 & EU541593 & \\
\hline V. halioticoli LMG18542T & AB000390 & DQ907349 & EU871952 & DQ907487 & AJ842430 & \\
\hline V. harveyi LMG4044T & X74706 & DQ907350 & EU118238 & DQ907488 & EF596430 & EF596215 \\
\hline V. hepatarius LMG20362T & AJ345063 & DQ907352 & JF316674 & DQ907491 & AJ842444 & AB298222 \\
\hline V. ichthyoenteri LMG19664T & AJ437192 & DQ907354 & HM771375 & DQ907493 & AJ842446 & \\
\hline V. kanaloae LMG20539T & AJ316193 & DQ481631 & FN908851 & DQ481657 & AJ842450 & \\
\hline V. lentus LMG21034T & AM162659 & DQ914234 & EU871959 & DQ914237 & AJ842452 & \\
\hline V. logei LMG21012T & AJ437616 & DQ907355 & EF380234 & DQ907494 & AJ842457 & \\
\hline V. mediterranei LMG11258T & HM771351 & DQ907356 & GU266288 & DQ907495 & AJ842459 & \\
\hline V. mytili LMG19157T & X99761 & DQ907358 & GU266287 & DQ907499 & AJ842472 & \\
\hline V. neptunius LMG20536T & AJ316171 & DQ907361 & GU266291 & DQ907503 & AJ842478 & AB298234 \\
\hline V. nigripulchritudo LMG3896T & X74717 & EF027347 & GU266290 & DQ907505 & AJ842480 & \\
\hline V. orientalis LMG7897T & X74719 & DQ907365 & EU118243 & DQ907507 & AJ842485 & EF380260 \\
\hline V. parahaemolyticus LMG2850T & X74720 & DQ907367 & GU266286 & DQ907509 & AJ842490 & \\
\hline$V \cdot$ pectenicida LMG19642T & Y13830 & DQ907368 & JN039143 & DQ907510 & AJ842491 & \\
\hline V. pomeroyi LMG20357T & AJ491290 & DQ481634 & EU871960 & DQ481660 & AJ842497 & \\
\hline V. salmonicida NCIMB2262T & X70643 & DQ907375 & EU118245 & DQ907517 & EF380243 & \\
\hline V. splendidus LMG19031T & X74724 & DQ481635 & EU118241 & DQ481661 & AJ842511 & \\
\hline V. tapetis LMG19706T & Y08430 & DQ907379 & HE795189 & DQ907520 & AJ842514 & \\
\hline V. tasmaniensis LMG20012T & AJ514912 & DQ481636 & EU871961 & DQ481662 & AJ842515 & \\
\hline V. tubiashii LMG10936T & X74725 & DQ907381 & JF316670 & DQ907521 & AJ842518 & \\
\hline V. vulnificus LMG13545T & X76333 & DQ907382 & GQ382226 & DQ907522 & AJ580890 & \\
\hline V. xuii LMG21346T & AJ316181 & DQ907384 & GU266284 & DQ907524 & AJ842529 & AB298254 \\
\hline
\end{tabular}




S. putrefaciens CN-32
Vibrio sp = V. tubiashii
04/002 1T2 (=LMG 27884 = CECT 8426)
07/038 T1
07/108 T1
07/110 T1
07/112 T1
07/116 T1
07/117 T1
07/118 T2 ( =LMG 27884 = CECT 8426)
07/119 T1
07/120 T1
V. tubiashii
LMG16851
R659
R674
R676
R677
R678
R711
R716
R722
R723
R731
R14825

$\begin{array}{llllll}\text { KF270470 } & \text { KF270480 } & \text { KF270492 } & \text { KF270460 } & \text { KF270502 } & \\ \text { KF270471 } & \text { KF270481 } & \text { KF270493 } & \text { KF270461 } & \text { KF270503 } & \\ \text { KF270472 } & \text { KF270482 } & \text { KF270494 } & \text { KF270462 } & \text { KF270504 } & \\ \text { KF270473 } & \text { KF270483 } & \text { KF270495 } & \text { KF270463 } & \text { KF270505 } & \\ \text { KF270474 } & \text { KF270484 } & \text { KF270496 } & \text { KF270464 } & \text { KF270506 } & \text { KF270490 } \\ \text { KF270475 } & \text { KF270485 } & \text { KF270497 } & \text { KF270465 } & \text { KF270507 } & \\ \text { KF270476 } & \text { KF270486 } & \text { KF270498 } & \text { KF270466 } & \text { KF270508 } & \\ \text { KF270477 } & \text { KF270487 } & \text { KF270499 } & \text { KF270467 } & \text { KF270509 } & \text { KF270491 } \\ \text { KF270478 } & \text { KF270488 } & \text { KF270500 } & \text { KF270468 } & \text { KF270510 } & \\ \text { KF270479 } & \text { KF270489 } & \text { KF270501 } & \text { KF270469 } & \text { KF270511 } & \end{array}$

AJ842520

EU717015

EU717030

EU717031

EU717032

EU717033

EU717060

EU717064

EU717068

EU717069

EU717073

AJ842522 


S. putrefaciens CN-32
Vibrio sp = V. tubiashii
04/002 1T2 (=LMG 27884 = CECT 8426)
07/038 T1
07/108 T1
07/110 T1
07/112 T1
07/116 T1
07/117 T1
07/118 T2 ( =LMG 27884 = CECT 8426)
07/119 T1
07/120 T1
V. tubiashii
LMG16851
R659
R674
R676
R677
R678
R711
R716
R722
R723
R731
R14825

$\begin{array}{llllll}\text { KF270470 } & \text { KF270480 } & \text { KF270492 } & \text { KF270460 } & \text { KF270502 } & \\ \text { KF270471 } & \text { KF270481 } & \text { KF270493 } & \text { KF270461 } & \text { KF270503 } & \\ \text { KF270472 } & \text { KF270482 } & \text { KF270494 } & \text { KF270462 } & \text { KF270504 } & \\ \text { KF270473 } & \text { KF270483 } & \text { KF270495 } & \text { KF270463 } & \text { KF270505 } & \\ \text { KF270474 } & \text { KF270484 } & \text { KF270496 } & \text { KF270464 } & \text { KF270506 } & \text { KF270490 } \\ \text { KF270475 } & \text { KF270485 } & \text { KF270497 } & \text { KF270465 } & \text { KF270507 } & \\ \text { KF270476 } & \text { KF270486 } & \text { KF270498 } & \text { KF270466 } & \text { KF270508 } & \\ \text { KF270477 } & \text { KF270487 } & \text { KF270499 } & \text { KF270467 } & \text { KF270509 } & \text { KF270491 } \\ \text { KF270478 } & \text { KF270488 } & \text { KF270500 } & \text { KF270468 } & \text { KF270510 } & \\ \text { KF270479 } & \text { KF270489 } & \text { KF270501 } & \text { KF270469 } & \text { KF270511 } & \end{array}$

AJ842520

EU717015

EU717030

EU717031

EU717032

EU717033

EU717060

EU717064

EU717068

EU717069

EU717073

AJ842522 